\title{
レーザー核融合ロケットの設計
}

\author{
中 島 秀 紀, 庄 山英 俊, 神 田幸 則 \\ (九州大学総合理工学研究科)
}

（1991年 3 月 15日受理 / 1991年 7 月12日改訂原稿受理）

\section{Design Study of Laser Fusion Rocket}

Hideki Nakashima, Hidetoshi Shoyama and Yukinori Kanda

(Received March 15, 1991/Revised Manuscript Received July 12, 1991)

\begin{abstract}
A design study was made on a rocket powered by laser fusion. Dependence of its flight performance on target gain, driver repetition rate and fuel composition was analyzed to obtain optimal design parameters of the laser fusion rocket. The results indicate that the laser fusion rocket fueled with DT or $\mathrm{D}^{3} \mathrm{He}$ has the potential advantages over other propulsion systems such as fission rocket for interplanetary travel.
\end{abstract}

Keywords :

rocket, laser fusion, $\mathrm{DT}, \mathrm{D}^{3} \mathrm{He}$, target gain, driver repetition rate,

\section{1. 序論}

「2019年の月面着陸50周年までに，火星に人類を送る。」-1990年 5 月，ブッシュ米大統領は宣言した 国家宇宙評議会（NSC）や航空宇宙局（NASA）等により，具体的な計画作りが進められている，また，ソ連 でも2010年ごろ有人火星探査を実施する長期構想がある。これは, いよいよ宇宙開発時代の本格的到来を告 げるものであり，人間が地球から活動領域を広げていこうとする具体的な第一歩を目指すものである．

火星は，人類が地球圈外へ進出し定住することができる唯一の天体である. 火星の大気には, 二酸化炭素 が豊富に存在し, 地下には水が凍結した状態で存在する。また, 地球人にとって, 次の住居地となるばかり でなく,ここでの経験は, 他の惑星の探査, 開発に重要なものとなるであろうし, 前哨基地の役目も担うで あろう。

従来の化学ロケットでは, 基地や居住地を建設するために必要な何百 ton もの資材等を運搬するには適

Department of Energy Conversion Engineering, Kyushu University, Kasuga, Fukuoka 816. 


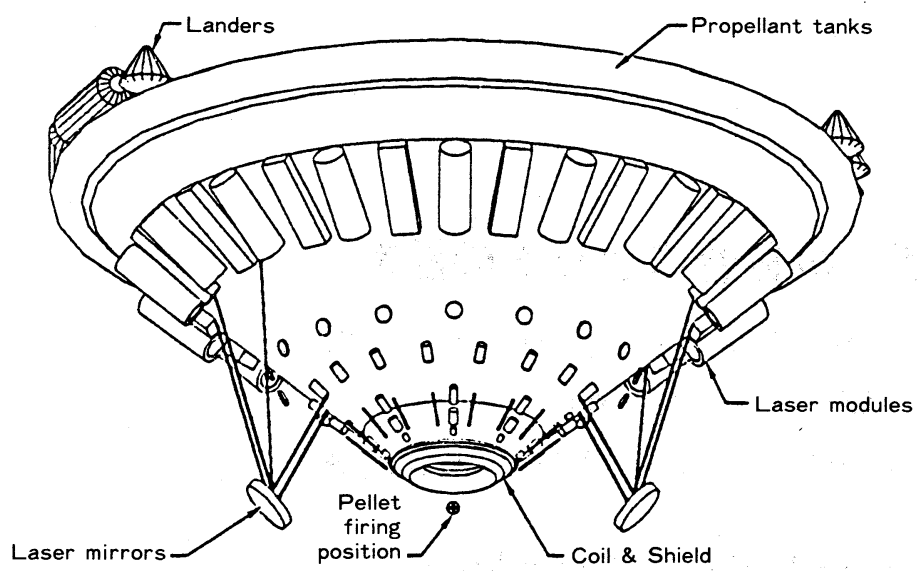

図1-1. 核融合ロケット概観図.
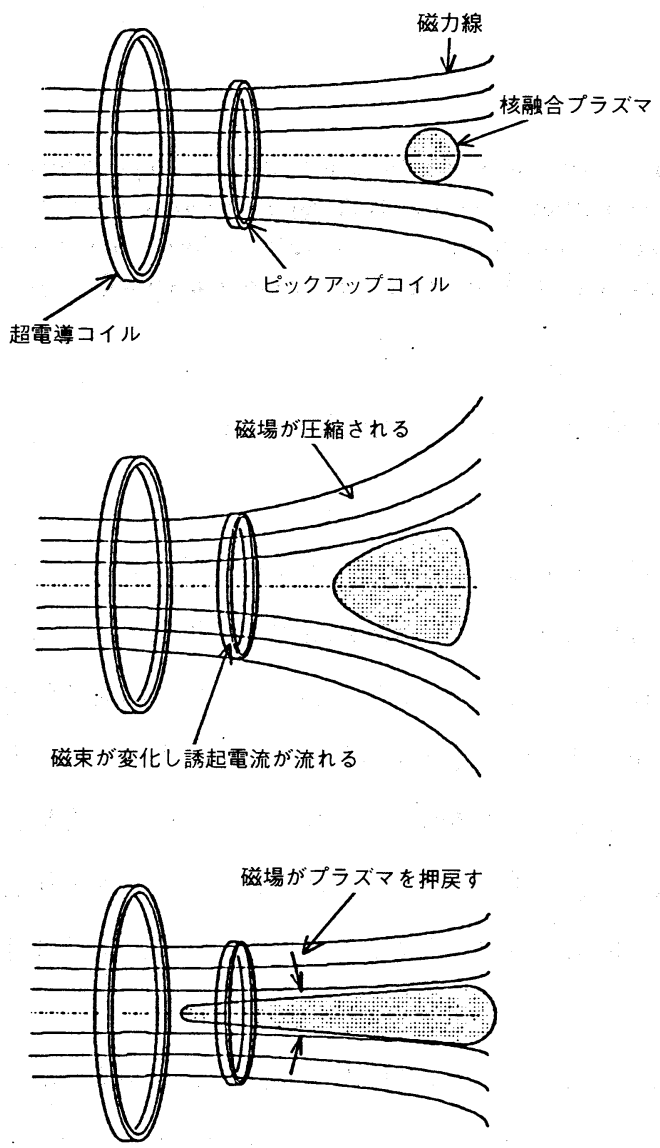

図1-2. 推力発生のメカニズム。
していない。そこで考えられ るのが, 慣性核融合口ケット （IFR）である。ロケットの 推進システムとして核融合を 利用した場合，エネルギー密 度が高いために，従来の化学 ロケットと比較してょり多く の推力を得ることができる. 推進材の排出速度は, $10^{7} \mathrm{~m} /$ $\sec$ 程度であり, 比推力（排 出速度を重力加速度で割った 值）は，10 $\mathrm{sec}$ となる。この 值は, 化学ロケットと比較し て, 2000倍程度であり，これ によってペイロードの割合が 多くとれる等の利点を持って いる. IFR は，2020年代の火 星基地の本格的建設には是非 必要な高速口ケットである。

核融合ロケットの概観は,

図1-1に示すようなものが考 えられている1）。核融合口 ケット推進システムについて 簡単に説明する。図1-2に, 推力発生のメカニズムを, ま た図1-3に質量とエネルギー の流れを示した。まず，核融 合燃料ターゲットを IFR の後 方に射出する。ターゲットが ある地点に達したときにレー ザーより照射を受け，そのエ ネルギーによって核融合反応 


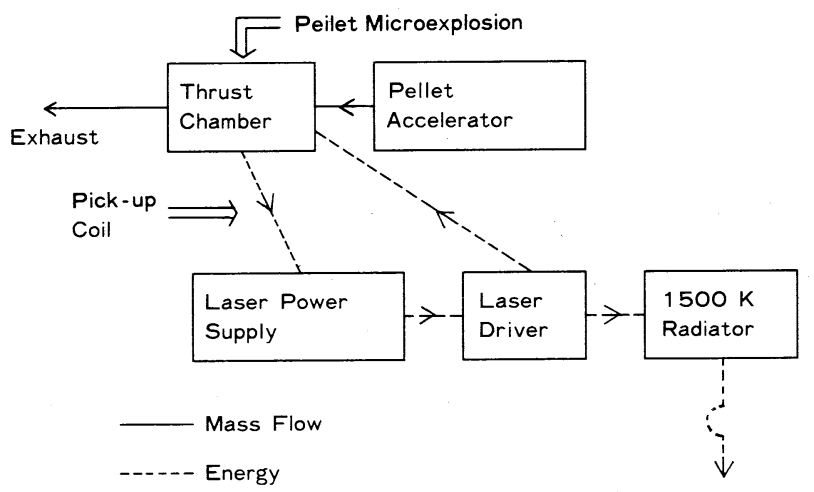

図1-3、質量とエネルギーの流れ図.
を生じさせる，核融合反応が起こると 反応のエネルギーによってターゲット は高エネルギーのプラズマとなって一 様に広がる。このプラズマが，コイル によって生じた強い磁場によって方向 を変えられ，IFRの後方に放出される ことによって推力を得る，また，核融 合で生じたエネルギーの内の一部は, ピックアップコイルと呼ばれる磁場内 におかれたコイルによって取り出さ

れレーザーに供給され，次の核融合反応を引き起こすために使われる．

本研究では，核融合ロケットの性能に対するターゲットゲイン等の依存性を検討することを主目的として いる，そのためには，まず，口ケットのパワープラント重量を求める必要があるので，核融合ロケットの各 コンポーネントについての設計を行う．

本論文の構成は，2 章で核融合ロケットのコンポーネント設計， 3 章でロケットの性能計算， 4 章で結論 となっている.

\section{2. 核融合ロケットのコンポーネント設計}

\section{2-1 ターゲット}

核融合ロケットは推力を得るために，プラズマと磁場の相互作用を利用する。また次のレーザーショット の為, やはり磁場との相互作用 (電磁唀導) を利用し, 電力を取り出す: 従って, ターゲットは核融合出 力，とりわけ荷電粒子の出力が大きいものが要求される.

$\mathrm{D}^{3} \mathrm{He}$ あるいは DD 燃料を夕ーゲットに利用すれば，核融合出力のうち荷電粒子の割合は大きい。しかし， 燃料を点火・燃焼させる為の爆縮に要求されるエネルギーは大きいことが予想され，ここで考える5 レーザーエネルギーでは，点火・燃焼が困難である．

表2-1，核融合燃料の性能

\begin{tabular}{|c|c|c|c|}
\hline Target & $\mathrm{D}^{3} \mathrm{He}$ & $\mathrm{DD}$ & $\mathrm{DT}$ \\
\hline Gain & 250 & 250 & 1500 \\
\hline $\begin{array}{c}\text { 核融合エネルギー中の } \\
\text { 荷電粒子割合 } \alpha_{\mathrm{p}}\end{array}$ & 0.90 & 0.60 & 0.25 \\
\hline 中性子割合 $\alpha_{n}$ & 0.01 & 0.25 & 0.60 \\
\hline 輻射割合 $\alpha_{\mathrm{x}}$ & 0.09 & 0.15 & 0.15 \\
\hline
\end{tabular}

一方，DT 燃料では，表2-1に示すように，核融合出力の中 で荷電粒子の占める割合はせいぜい（夕ーゲット中での中性 子加熱の効果を考慮しても） $25 \%$ 程度であり， $\mathrm{D}^{3} \mathrm{He}$ の $90 \%$ ， DD の $60 \%$ な゙と比較すると小さい2）。しかし，点火は容易 であり，最終的に利用できる荷電粒子のエネルギーは大きい ものが期待される，従って，ここではゲイン（核融合出力／ レーザーエネルギー) を $G$, 荷電粒子の核融合出力中での割 
合を $\alpha_{\mathrm{p}}$ とすれば, $G \times \alpha_{\mathrm{p}}$ の大きいものが望ましく,これが燃料選択の際のメリットの指標となり, DT 燃料が,この值がいちばん大きいと期待される.

最近，月面に ${ }^{3} \mathrm{He}$ が豊富に存在することが発見された。また，その ${ }^{3} \mathrm{He}$ を採取し，核融合燃料として利用 することも考えられている，上に述べた様に $\mathrm{D}^{3} \mathrm{He}$ 反応を利用すれば，荷電粒子の割合は増加する，従っ て，DT 燃料に $G \times \alpha_{\mathrm{p}}$ の指標を最大化する様に $\mathrm{D}^{3} \mathrm{He}$ 燃料を添加することも考えられる.

次にターゲットの構造を考えてみよう，核融合ロケットでは，推力を増大させる目的で，核融合燃料の周 囲に推進材をおき, 核融合エネルギーで, この推進材もプラズマ化する，核融合出力 $P$ を定とすれば, 推力 $T$ は

$$
T=m v=(2 m P)^{1 / 2}
$$

と表せる。ここで $m$ は燃料+推進材の重量である，核融合燃料のみでは，数十 $\mathrm{mg}$ であるが，推進材もプ ラズマ化することにより，mが増大し推力も増加する，但し，推進材を大きくすれば，それをプラズマ化す るためのエネルギーも大きくなる。例えば水素を推進材として用いると，そのイオン化エネルギーには， $I=13.6 \mathrm{eV} /$ 原子が必要である。従って固体水素 $1 \mathrm{~g}$ の場合 $1.31 \mathrm{MJ} / \mathrm{g}$ のエネルギーが必要となる，イオン化 すなわちプラズマ化しなければ，磁場と相互作用せず推力へ利用できないことになる．実際にどの程度の推 進材がイオン化するかは, 状態方程式（EOS）や原子過程を組み込んだコードでシミュレーションを行い, 確認しておく必要がある。

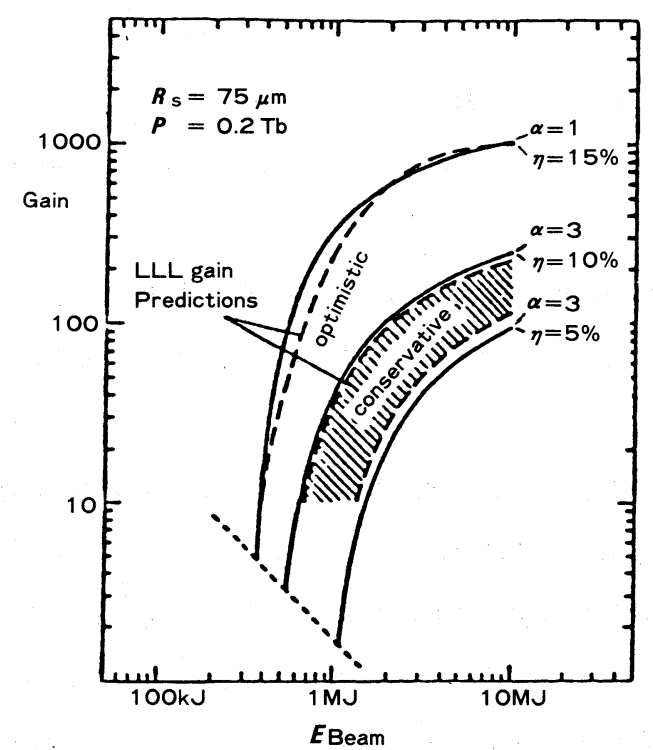

図2-1 ドライバーエネルギーに対する

核融合ペレットゲイン図.
上に述べた様に，核融合燃料の回りに推進材を配置 することになれば，直接照射型よりもむしろキャノン ボール（間接照射）型のターゲットが有望であろう。 推進材でキャビティ（空洞）をつくりその中心にター ゲットを配置し，レーザー光は推進材中にあけられた 孔を通してキャビティに導入される。このターゲット を利用する場合の欠点は, ターゲット構造が複雑にな り，直接照射ターゲットに比較して，より高度のター ゲット制作技術が要求されること，またX線放出のた めの Au など余分な材料が必要であり, ターゲット 重量を増加させることにある。

また，ゲインであるが，等圧モデルにより概算する ことができ，それを図2-1に示した3）。ここでは，レー ザーエネルギー5MJに対して，ゲインを1500，1000， 500の場合について検討する. 


\section{2-2 燃焼室}

\section{2-2-1 磁場強度 ${ }^{4)}$}

核融合によって生じたエネルギーは，プラズマ，輻 射, そして中性子の形で放出される。そそのうちプラズ マは, 磁場によってその運動方向を変化させることに より, 推力を得ることができる。磁場は, 超電導コイ ル（SCM）によって生成される。コイルと核融合爆発 点の体系は，図2-2の様に設計する．

IFR 構造物にプラズマ片が衝突せずに，その方向を 変えるような磁場強度が必要である。ここでは, 核融 合爆発点の周りの磁場強度は, 一様であると仮定して 求める。すなわち，（磁場のエネルギー）＝（プラズ

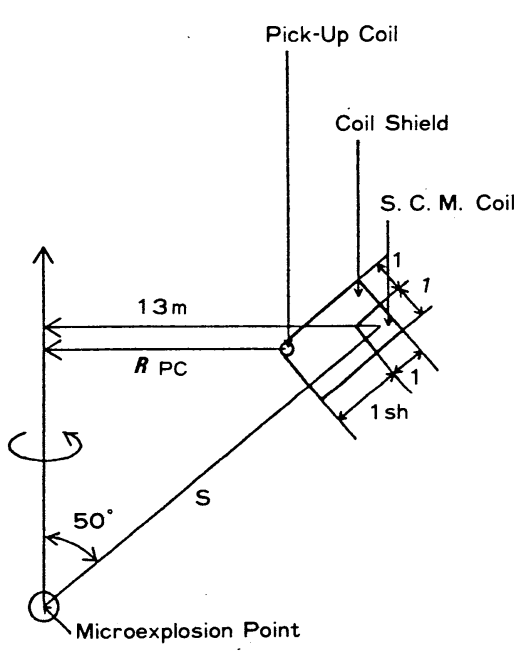

図2-2、設計に用いる燃焼室の体系図. マのエネルギー）となる磁場強度が, 最低限必要とさ れる．爆発点での磁場強度を $B_{0}$ とすれば，上の式は

$$
\frac{B_{0}^{2}}{2 \mu_{0}} \times \frac{4 \pi}{3} \times(0.8 s)^{3}=\alpha_{\mathrm{p}} \times E \times G
$$

と表せる。ここで, $s$ は核融合爆発点からコイルまでの距離であり, プラズマはこの距離の 8 割程度まで広 がるものとした，残りの 2 割は，SCM 防護のための中性子遮蔽等に用いられる．また， $\mu_{0}$ は真空の透磁率， $\alpha_{\mathrm{p}}$ は核融合エネルギー中で荷電粒子の占める割合， $E$ はドライバーエネルギー，Gはペレットゲインであ る。核融合爆発点からコイルに近づくにつれて磁場強度は強くなるので, この式で求める磁場強度はかなり 保守的な値となる。

\section{2-2-2 超電導コイル ${ }^{4), 5)}$}

この様な磁場強度を静的につくり出すには, 超電導コイルを用いれば容易である. 超電導電磁石用線材と しては, $\mathrm{NbTi}, \mathrm{Nb}_{3} \mathrm{Sn}, \mathrm{V}_{3} \mathrm{Ga}$ の三種類が実用的であるが, 高磁場強度内で高臨界電流密度をとる事ができる $\mathrm{V}_{3} \mathrm{Ga}$ をここでは用いる. また, 安定化材として $\mathrm{Al}$ を用い, 複合構造とする。 $\mathrm{V}_{3} \mathrm{Ga}$ と $\mathrm{Al}$ の断面積比を $2: 1$ とする. $\mathrm{V}_{3} \mathrm{Ga}$ の臨界温度は, 約 $16.8 \mathrm{~K}$ であるので, 冷却材として液体 $\mathrm{He}$ を用いる. 構造は, バ ンドル導体型とし, 線材は有効冷却面積を大きくするために, より線にし, 容器におさめ, 冷却材は素線の 隙間を通す，液体 $\mathrm{He}$ 温度 $(4.2 \mathrm{~K})$ 付近では, 磁場強度を10 20T とすれば, $\mathrm{V}_{3} \mathrm{Ga}$ の臨界電流密度は, $10^{8}$ $\sim 10^{9}\left(\mathrm{~A} / \mathrm{m}^{2}\right)$ となる。コイル素線 1 本 1 本には, 絶縁材が張り付けられ, 素線間の影響がでないようにさ 
れるが，コイルの体積の $40 \%$ は冷却材や絶縁材によって占められ，残り60\%をコイル素線と安定化材が占め るものとする.コイル電流 $I_{\mathrm{c}}$, コイル素線部の断面積 $S_{\mathrm{CSC}}$, 及びコイル重量 $M_{\mathrm{c}}$ は, 次式により求める.

$$
\begin{aligned}
& I_{\mathrm{c}}=\frac{2 B_{0} s}{\mu_{0}} \\
& S_{\mathrm{csc}}=\frac{I_{\mathrm{c}}}{J_{\mathrm{c}}} \\
& M_{\mathrm{c}}=2 \pi R_{\mathrm{c}} S_{\mathrm{csc}} \times\left(\rho_{\mathrm{V} 3 \mathrm{Ga}}+\frac{2}{3} \rho_{\mathrm{Al}}\right)
\end{aligned}
$$

ここで, $J_{\mathrm{c}}$ はコイル素線部の臨界電流密度, $R_{\mathrm{c}}$ はコイル半径, $\rho_{\mathrm{V} 3 \mathrm{Ga}}$ は $V_{3} \mathrm{Ga}$ の密度, $\rho_{\mathrm{Al}}$ は $\mathrm{Al}$ の密 度であり， $R_{\mathrm{c}}=13 \mathrm{~m}, \rho_{\mathrm{V} 3 \mathrm{Ga}}=6.1 \mathrm{~g} / \mathrm{cm}^{3}, \rho_{\mathrm{Al}}=2.7 \mathrm{~g} / \mathrm{cm}^{3}$ を用いる。 また, 冷却材と絶縁材の重量は無視し た。ピーク磁場強度が18〜19T となるような断面積 $S_{\mathrm{csc}}$ を決め, $J_{\mathrm{c}}$ は臨界電流密度以下である必要が ある。

\section{2-2-3 コイルカン（容器）}

コイルは, それ自身の作り出す磁場によって, 外側へのローレンッカを受ける. その力は, 次式により求 める.

$$
F_{\text {hoop }}=\frac{1}{2} \quad \mu_{0} I_{\mathrm{c}}^{2} \quad\left(\ln \frac{8 R_{\mathrm{c}}}{a_{\mathrm{c}}}-\frac{3}{4}\right)
$$

ここで, $F_{\text {hoop }}$ がコイルの受けるローレンツカを表し, $I_{\mathrm{c}}$ はコイル電流, $R_{\mathrm{c}}$ はコイル半径， $a_{\mathrm{c}}$ はコイル 断面を円形として場合の断面半径を表す，このローレンッカにより，コイルはフープ応力を受けるが, コイ ルカンによって，そのフープ応力を吸収させる，コイルカンには，グラスファイバーを用いる．グラスファ イバーの密度は $\rho_{\mathrm{gf}}=1.89 \mathrm{~g} / \mathrm{cm}^{3}$ であり, また使用応力として $\sigma_{\mathrm{u}}=330 \mathrm{MPa}$ 用いる ${ }^{6)}$. コイルカン断面積 $S_{\mathrm{cc}}$, 重量 $M_{\mathrm{cc}}$ は次式で求める.

$$
\begin{aligned}
& S_{\mathrm{cc}}=\frac{F_{\text {hoop }}}{2 \pi \sigma_{\mathrm{u}}} \\
& M_{\mathrm{cc}}=2 \pi R_{\mathrm{c}} S_{\mathrm{cc}} \rho_{\mathrm{gf}}
\end{aligned}
$$


コイル表面には, 核融合爆発の瞬間毎に, 次式で表せるような渦電流が流れる ${ }^{7)} . \nabla \times B=\mu_{0}{ }^{i} よ り$,

$$
i=\frac{B_{0}}{\mu_{0} \tau}
$$

ここで, $i$ は渦電流の電流密度, $\tau$ は渦電流の流れる表皮厚さであり， $て$ は次式で求める

$$
\tau=\left(\frac{\rho_{\mathrm{e}} t_{\mathrm{pc}}}{\mu}\right)^{1 / 2}
$$

コイルカンの表面に導電性のある薄膜を張り付け，そこに渦電流を流すようにする，薄膜として，SUS を用 いる. SUS の体積抵抗率は, $\rho_{\mathrm{e}}=20 \times 10^{-8} \Omega \cdot \mathrm{m}$ である.この薄膜の重量 $M_{\mathrm{SUS}}$ は次式で求めることがで きるが，およそ1ton 以下であり，パワープラント重量への影響は，ほとんど無い様なものと考えられる。

$$
M_{\mathrm{SUS}}=\rho_{\mathrm{sus}} \times 2 \pi R_{\mathrm{c}} \times \tau \times l
$$

ここで， $\rho_{\text {SUS }}$ はSUSの密度，lはコイル幅であり， $\rho_{\text {SUS }}=7.9 \mathrm{~g} / \mathrm{cm}^{3}$ を用いる，また， $l=\sqrt{S_{\mathrm{csc}} \times 15 / 4}$ で求める. 重量への影響よりもむしろ, この渦電流によって生ずる熱損失の方が大事であ る。熱損失 $\left(Q_{\mathrm{Eddy}}\right)$ は, 次式により求める.

$$
\begin{aligned}
Q_{\mathrm{Eddy}} & =R \times I^{2} \times t_{\mathrm{pc}} \times f \\
& =\left(\frac{\rho_{\mathrm{e}} \times 2 \pi R_{\mathrm{c}}}{\tau l}\right) \times(i \times \tau l)^{2} \times t_{\mathrm{pc}} \times f
\end{aligned}
$$

ここで， $t_{\mathrm{pc}}$ はプラズマが磁場を押し広げる時間， $f$ は核融合周波数である. この熱損失は, 輻射による加 熱と比較すると 3 桁程度小さいので，ここでは排熱については考えないが，あまりにも大きな值になった場 合は考える必要がある。

\section{2-2-4 輻射シールド4)}

核融合エネルギーの一部は, 輻射の形で放出される。低エネルギーの輻射は物質のごく表面で吸収され る.この為, コイルシールドの表面には, 低エネルギーの輻射に対して, 長い平均自由行程を持つ Be を張 り付ける。また, Beに比べ, 機械的強度が高く, 熱伝導率も高く, かつ低エネルギーの輻射に対する遮蔽 
能力が劣らない $\mathrm{BeO}$ と, $\mathrm{Be}$ を交互の層 $(\mathrm{Be} / \mathrm{BeO})$ にし, $\mathrm{Be}$ 層と $\mathrm{BeO}$ 層の厚さの比を $1 ： 5$ とする. シールドに入射してくる輻射の単位面積当たりのエネルギー $Q_{\mathrm{x}}$ は，次の式で与えられる．

$$
Q_{\mathrm{x}}=\alpha_{\mathrm{x}} \times E \times G \times f \times \frac{1}{4 \pi S_{\mathrm{x}}^{2}}
$$

ここで， $S_{\mathrm{x}}$ は核融合爆発点からコイルシールド端までの距離であり，Eはドライバーエネルギー，Gは ペレットゲイン，fは核融合周波数， $\alpha_{\mathrm{x}}$ は核融合エネルギー中で輻射の占める割合である. Be の熱伝導 率を $K_{\mathrm{Be}}(\mathrm{W} / \mathrm{mK})$ とし, $\mathrm{BeO}$ の熱伝導率を無限大と仮定すれば, 輻射による $\mathrm{Be} / \mathrm{BeO}$ 層の上昇温度は,

$$
\Delta T=\frac{Q_{\mathrm{x}}}{K_{\mathrm{Be}}} \times \frac{t}{6}
$$

となる。ここで, $t$ は輻射シールド層の全厚である

Be の融点は, 約1550K である。また, コイルシールドは約1500K で使用されるので， $\Delta T$ は約50K 以内 におさえる必要がある。従って, 全厚 $t$ はせいぜい数 $\mathrm{mm}$ 程度となるので, 重量は計算していない.

\section{2-2-5 中性子シールド4)}

核融合爆発により生じる中性子は, LiH によりなる中性子シールドにより遮蔽され，コイルへの熱進入を 抑える.コイルシールドの厚さ $\left(l_{\mathrm{sh}}\right)$ は, 次式により求める.

$$
l_{\mathrm{sh}}=\lambda_{\mathrm{LiH}} \times \ln \frac{P_{\text {in }}}{P_{\text {out }}}
$$

ここで， $\lambda_{\mathrm{LiH}}$ は, 中性子に対する $\mathrm{LiH}$ の平均自由行程, $P_{\mathrm{in}}$ はコイルジールドへ進入してくる中性子の エネルギー, $P_{\text {out }}$ はコイルシールドから出ていくエネルギーである.ここでは, $P_{\text {out }}=50 \mathrm{~W}$ で計算を行う． $P_{\text {in }}$ については, 次式で求める.

$$
P_{\text {in }}=\alpha_{\mathrm{n}} \times E \times G \times f \times \frac{\Omega}{4 \pi}
$$

ここで， $\alpha_{\mathrm{n}}$ は核融合エネルギー中で中性子の占める割合， $\frac{\Omega}{4 \pi}$ はコイルの占める立体角である，中性子 
シールドの重量は，次式で求める，ここで，シールドは図2-2の様にコイルを覆っているものとする，中心 軸側にもシールドを設けたのは，反対側で散乱された中性子がコイルに侵入するのを防ぐためである。

$$
\begin{aligned}
& M_{\mathrm{csh}}=\rho_{\mathrm{LiH}} \times 2 \pi R_{\mathrm{c}} \times S_{\mathrm{csh}} \\
& S_{\mathrm{csh}}=l^{2}+2 \times l \times l_{\mathrm{sh}}
\end{aligned}
$$

$S_{\mathrm{csh}}$ は, シールドを含めたコイル断面積を表す.

\section{2-2-6 排熱用ヒートパイプ (ラジエーター) ${ }^{4), 8)}$}

シールドに入射するエネルギーは，ヒートパイプを用いて放熱される．放熱されるべきエネルギーを $Q$, ヒートパイプの長さを $L$, 直径を $d$, 本数を $n$ としたとき,これらは次の方程式により求めることがで きる。

$$
\left\{\begin{array}{l}
Q=\left(\alpha_{\mathrm{x}}+\alpha_{\mathrm{n}}\right) \times E \times G \times f \times \frac{\Omega}{4 \pi} \times 2 \\
N n d=2 \pi R_{\mathrm{c}} \\
Q=N n \times \frac{\pi d^{2}}{4} \times \frac{\lambda_{\mathrm{a}}}{L^{1 / 3}} \\
Q=N n \times \pi d L \times \lambda_{\mathrm{R}}
\end{array}\right.
$$

ここで, $\mathrm{N}$ は隕石防護係数 ${ }^{8)}, \lambda_{\mathrm{a}}$ はヒートパイプの軸方向熱流速， $\lambda_{\mathrm{R}}$ はヒートパイプの単位表面積当た りの輻射率である。コイルシールドに用いられる $\mathrm{LiH}$ の解離温度は $1220 \mathrm{~K}$ であるので, ヒートパイプはそれ 以上の温度で使用されなければならない。ここでは, $1500 \mathrm{~K}$ で使用するものとする. 放射率を $\varepsilon=0.85$ とす れば， $\lambda_{\mathrm{R}}=2.44 \times 10^{5}\left(\mathrm{~W} / \mathrm{m}^{2}\right)$ となる。 また, ヒートパイプ内に使用する媒体を $\mathrm{Li}$ とし，液体部のヒート パイプ中に占める割合 $(\mathrm{c})$ を半径比で 0.02 とすれば, $\lambda_{\mathrm{a}}=1.46 \times 10^{8}\left(\mathrm{~W} / \mathrm{m}^{2}\right)$ となる ${ }^{8)}$ : (2-2-18) 式の 右辺の係数 2 は，図2-2に示す様にシールドを含めるとコイルだけの 2 倍の立体角になるからである．

\section{2-3 パワー・システム}

\section{2-3-1 ピックアップコイル4)}

レーザーの励起等に用いられるエネルギーは, 核融合爆発のエネルギーからピックアップコイルによって 取り出される，プラズマが磁場を圧縮し，コイル内の磁束変化が起こり，コイルにはファラデーの電磁誘導 により電流が流れる (図1-2参照) 。ピックアップコイルにより得られるエネルギーは, 次の方程式により 求める。 


$$
\left\{\begin{array}{l}
V_{\text {plasma }}=\left(\frac{2 \times E \times G \times \alpha_{\mathrm{p}}}{m_{\mathrm{p}}}\right)^{1 / 2} \\
t_{\mathrm{pc}}=\frac{R_{\mathrm{pc}} / 2}{V_{\mathrm{plasma}}} \\
V_{\mathrm{pc}}=\frac{\pi R_{\mathrm{pc}}^{2} B_{0}}{t_{\mathrm{pc}}} \\
L_{\mathrm{pc}}=\mu_{0} R_{\mathrm{pc}}\left(\ln \frac{8 \times R_{\mathrm{pc}}}{a_{\mathrm{pc}}}-\frac{7}{4}\right) \\
I_{\mathrm{pc}}=\frac{V_{\mathrm{pc}}}{\left(2 \pi / t_{\mathrm{pc}}\right) \times L_{\mathrm{pc}}} \\
E_{\mathrm{out}}=V_{\mathrm{pc}} \times I_{\mathrm{pc}} \times t_{\mathrm{pc}}
\end{array}\right.
$$

ここで, $V_{\text {plasma }}$ はプラズマの速度， $E$ はドライバーエネルギー，Gはペレットゲイン， $\alpha_{\mathrm{p}}$ は核融合エネ ルギー中の荷電粒子が占める割合, $m_{\mathrm{p}}$ は夕ーゲット 1 個当たりの重量, $t_{\mathrm{pc}}$ はプラズマが磁場を押し広げ る時間, $R_{\mathrm{pc}}$ はピックアップコイル半径, $V_{\mathrm{pc}}$ は誘起電圧, $B_{0}$ は体系内の磁場強度, $L_{\mathrm{pc}}$ はピックアップコ イルの自己インダクタンス， $a_{\mathrm{pc}}$ はピックアップコイル断面半径， $I_{\mathrm{pc}}$ は誘起電流， $E_{\mathrm{out}}$ はピックアップ コイルにより取り出されるエネルギーをそれぞれ表す。ピックアップコイルは, 図2-20ようにコイルシー ルドの最も内端に配置する。断面構造は，図2-3の通りである，磁場が変化するのは，プラズマがピック アップコイル半径の半分以上広がった時か

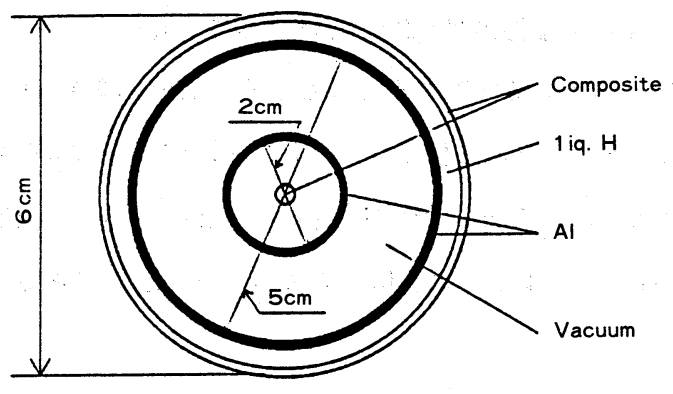

図2-3. ピックアップコイル断面図.

$$
\begin{aligned}
& \text { らとして }, t_{\mathrm{pc}} \text { を計算している. } \\
& \text { ここで取り出すエネルギーは, レーザー }
\end{aligned}
$$
照射等に供給される。ドライバー出力エネ ルギーは $E=5.28 \mathrm{MJ}$, レーザー効率 $\eta=6$ \%であるので, 1 回のレーザー照射のため に必要なエネルギーは，E $E / \eta=88.0 \mathrm{MJ}$ で ある。 1 回の核融合により取り出されるエ ネルギーが, 次の核融合を起こすためのド ライバーエネルギーを照射するためにすべ

て使われるとしても，1回の核融合により $88.0 \mathrm{MJ}$ は必要とされる。核融合エネルギー中で荷電粒子の占め るエネルギーのうち回収される割合は，せいぜい $10 \%$ なで，ドライバーエネルギー $5 \mathrm{MJ}$ で DT 燃料を用い た場合， $\alpha_{\mathrm{p}}=0.25$ なので, ゲインは約700以上必要となる。

ピックアップコイルに実際に電流が流れるのは, 導電体表面のわずかな部分だけであり，その表皮厚さ $\delta$ 
は，次式で表される7).

$$
\delta=\left(\frac{\rho_{\mathrm{e}} t_{\mathrm{pc}}}{\mu_{0}}\right)^{1 / 2}
$$

導電体には， $\mathrm{Nb}$ を用いる。高温の Nbに対しては, $\rho_{\mathrm{e}}=50.8 \times 10^{-8}(\Omega \cdot \mathrm{m})$ である ${ }^{4)} ， t_{\mathrm{pc}}$ は, $10^{-5}$ $\mathrm{sec}$ 程度が最大となるので， $\delta$ は数 $\mathrm{mm}$ あれば充分である。

$\mathrm{Nb}$ 導体には電流が流れることにより次のようなジュール熱損失が生じる.

$$
\begin{aligned}
Q_{\text {loss }} & =R I^{2} \\
& =\left(\frac{\rho_{\mathrm{e}} \times 2 \pi R_{\mathrm{pc}}}{2 \pi a_{\mathrm{pc}} \times \delta}\right) \times I_{\mathrm{pc}}{ }^{2} \times t_{\mathrm{pc}} \times f
\end{aligned}
$$

この熱は，ピックアップコイル内部をヒートパイプの構造の一部にしコイル内部にLi 排除される。

ピックアップコイルには，次式で表される外側へのローレンッカが働く．

$$
F_{\mathrm{pc}}=I_{\mathrm{pc}} \times B_{0} \times \pi R_{\mathrm{pc}}
$$

この為, コイルは次のような応力を受ける ${ }^{9)}$ が，コイル中心に配置する coreによって吸収させる。

$$
\sigma_{\mathrm{pc}}=\left(\frac{F_{\mathrm{pc}}}{\pi R_{\mathrm{pc}} \times 2 a_{\mathrm{core}}}\right) \times\left(\frac{t_{\mathrm{pc}}}{2 a_{\mathrm{core}}}\right) \times\left(\frac{E}{\rho}\right)^{1 / 2}
$$

core には Nb 合金を用いるが，上記のコイルにかかる応力は， Nb の使用応力（100MPa 程度）以下に抑え なければならない. ピックアップコイルの重量は次式で表される.

$$
M_{\mathrm{pc}}=2 \pi R_{\mathrm{pc}} \times\left\{S_{\mathrm{Nb}} \times \rho_{\mathrm{Nb}}+S_{\mathrm{Li}} \times c^{2} \times \rho_{\mathrm{Li}}+S_{\mathrm{core}} \times \rho_{\text {core }}\right\}
$$

\section{2-3-2 電送線 ${ }^{4)}$}

ピックアップコイルにより得られたエネルギーの輸送には, 戝2-4の様な断面構造をもつ電送線が用いら れる。この線の単位長当たりの抵抗は, 次式で与えられる。 


\section{核融合研究 第66巻第 3 号 1991年 9 月}

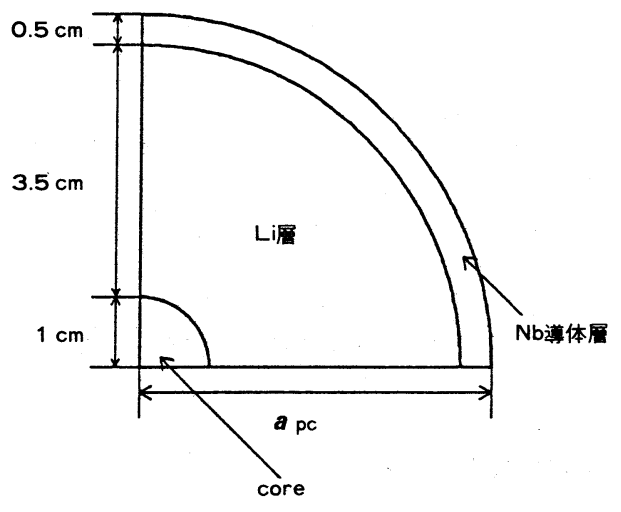

図2-4. 電送線断面図.

$$
\frac{R_{\mathrm{TL}}}{L_{\mathrm{TL}}}=\frac{\rho_{\mathrm{e}}}{\pi \delta} \times\left(\frac{1}{d_{\text {in }}}+\frac{1}{d_{\text {out }}}\right)
$$

$\delta$ は電流の流れる表皮厚さである。導体には $\mathrm{Al}$ を低温 $(20 \mathrm{~K})$ で用いる。このとき, $\rho_{\mathrm{e}}=$ $3.3 \times 10^{-11} \Omega \cdot \mathrm{m}$ である。 $L_{\mathrm{TL}}$ は電送線の長さ であり $L_{\mathrm{TL}}=200 \mathrm{~m}$ とし, $R_{\mathrm{TL}} I_{\mathrm{TL}}{ }^{2}=2.0 \mathrm{kA}$ とな るように設定すれば, 線 1 本当たりの電流值

$I_{\mathrm{TL}}$ が与えられる，ピックアップコイルにより得られる電流 $I_{\mathrm{pc}}$ を輸送するのに必要な本数 $\left(I_{\mathrm{pc}} / I_{\mathrm{TL}}\right)$ を配置する必要がある。重量は次式で与えられる。

$$
M_{\mathrm{TL}}=\rho_{\mathrm{TL}} \times L_{\mathrm{TL}} \times \frac{I_{\mathrm{pc}}}{I_{\mathrm{TL}}}
$$

電送線にも熱損失が生じる.

$$
Q_{\text {loss }}^{\mathrm{TL}}=R_{\mathrm{TL}} \times I_{\mathrm{TL}}^{2} \times t_{\mathrm{pc}} \times f \times \frac{I_{\mathrm{pc}}}{I_{\mathrm{TL}}}
$$

電送線は低温で使用されるので,この熱は除去されねばならない. 熱除去は後述する冷凍系を用いて 行う.

\section{2-3-3 キャパシター・バンク}

レーザー照射の為のエネルギーは，キャパシター・バンクに一時的に蓄えられる。これは, コンデンサー を並列に並べたものである，プレート（電極）面積 $A$, プレート間隔 $d$, 枚数 $n$ とすれば, 次の方程式が 成り立つ。

$$
C=\frac{\varepsilon_{0} n A}{d}
$$




$$
\begin{aligned}
& E_{\mathrm{st}}=\frac{\varepsilon_{0} E_{\mathrm{m}}{ }^{2}}{2} \times n A d \\
& V=E_{\mathrm{m}} d
\end{aligned}
$$

ここで, Cはコンデンサーの電気容量, $E_{\mathrm{m}}$ は絶縁耐力であり， $E_{\mathrm{m}}=100 \mathrm{MV} / \mathrm{m}$ とする． $E_{\mathrm{st}}$ は蓄えねばな らないエネルギーであり, ドライバー出力エネルギーE=5.28MJ, ドライバー効率 $\eta=6 \%$ とれね゙, $E_{\mathrm{st}}$ $\geqq E / \eta=88.0 \mathrm{MJ}$ である、Vは，コンデンサーの電位であるが，Vがあまり大きいと，ピックアップコイル からのエネルギー取り込みが困難になる。従ってプレート間隔 $d$ は $10 \mathrm{~cm}$ 程度が限界となる。コンデンサー に蓄えられたエネルギーは, 10nsec のレーザー励起時間の間に, 電子ビーム発生装置へ送られねばならな い，プレート面積 $A$ は，光の通過時間によって制限される．通過時間 $\tau_{\mathrm{L}}=30 \mathrm{nsec}$ 程度にすれば, $A=\left(C_{0}\right.$ $\left.\times \tau_{\mathrm{L}}\right)^{2}=81 \mathrm{~m}^{2}$ となる．ここで， $C_{0}$ は光速である，以上より，枚数 $n$ も自動的に与えられる．コンデンサー の重量は, 次式で与えられる。

$$
M_{\text {cap }}=n \times A \times t_{\text {cap }} \times \rho_{\text {cap }}
$$

ここで, $t_{\text {cap }}$ はプレート厚さで, $0.1 \mathrm{~mm}$ とし， $\rho_{\text {cap }}$ はプレートの密度で, $9.7 \mathrm{~g} / \mathrm{cm}^{3}$ とする

\section{2-4 ドライバー・システム}

\section{2-4-1 レーザー4),10)}

ICF 用レーザーは，短波長であればあるほどターゲットの爆縮に好都合である。しかし，光学材料などの 制限から実用上の大出力レーザーの発信波長としては, KrF レーザーの248nm という波長が最短であろう.

ターゲット入力值を $5 \mathrm{MJ}$, 増幅器 $(\mathrm{KrF}$ ガス) -ターゲット間の損失を $5 \%$ 程度とすると, レーザー出力 は5.25MJ 必要となる。現在のレーザー開発目標は，1基当たり100〜300kJ なので $5.25 \mathrm{MJ}$ を得るために 220 $\mathrm{kJ}$ の増幅器を24基用いる.

增幅器の体積当たりの取り出し可能エネルギーを $10 \mathrm{~J} / l$ とすると, 1 基当たりの体積は, $22 \mathrm{~m}^{3}$ となる. また，ミラーの照射損傷を引き起こさない限界照射強度を $40 \mathrm{~kJ} / \mathrm{m}^{2}$ とすると, 増幅器の断面積は, $5.5 \mathrm{~m}^{2}$ と なり, 長さが $4 \mathrm{~m}$ と決まる.

$\mathrm{KrF}$ ガスと容器の重量は, それぞれ以下の式で求める.

$$
M_{\text {gas }}=24 \times \frac{P_{\mathrm{L}} V_{\mathrm{L}}}{R T_{\mathrm{L}}} \times \rho_{\text {gas }}
$$




$$
M_{\text {wall }}=24 \times\left(t_{1}+t_{2}\right) \times\left(2 \pi R_{\mathrm{L}} \times L_{\mathrm{L}}+2 S_{\mathrm{L}}\right) \times \rho_{\text {wall }}
$$

$M_{\mathrm{gas}}, M_{\text {wall }}$ がそれぞれ $\mathrm{KrF}$ ガスど容器の重量を表し， $P_{\mathrm{L}}$ はガスの内圧， $V_{\mathrm{L}}$ はレーザーガス体積， $R$ は気体定数, $T_{\mathrm{L}}$ はレーザー使用温度, $L_{\mathrm{L}}$ は増幅器の長さ, $S_{\mathrm{L}}$ はその断面積, $R_{\mathrm{L}}$ は断面を円とした時の半 径， $\rho_{\text {gas }}$ はレーザーガスの密度， $\rho_{\text {wall }}$ は壁材の密度である. $P_{\mathrm{L}}=1 \mathrm{~atm}, T_{\mathrm{L}}=1500 \mathrm{~K}, \rho_{\mathrm{gas}}=39.9 \mathrm{~g} / \mathrm{mol}$ ， $V_{\mathrm{L}}=22 \mathrm{~m}^{3}, L_{\mathrm{L}}=4 \mathrm{~m}, S_{\mathrm{L}}=5.5 \mathrm{~m}^{2}, R_{\mathrm{L}}=1.32 \mathrm{~m}$ を用いる：ここで，ガスは $\mathrm{Ar}$ ガス $100 \%$ と仮定した。レーザー 容器は，隕石が貫通してしまうと使用できなくなるので，二重構造とする， $t_{1}, t_{2}$ はそれぞれ容器の外壁, 内壁の厚さである，材質は，Mo 合金とする．（ $\left.\sigma_{\mathrm{u}}=70 \mathrm{MPa}, \rho=10.2 \mathrm{~g} / \mathrm{cm}^{3}\right)$

内壁厚さ $t_{2}$ は，内压により決定する。

$$
t_{2}=\frac{P_{\mathrm{L}} R_{\mathrm{L}}}{\sigma_{\mathrm{u}}}=1.9 \mathrm{~mm}
$$

外壁厚さ $t_{1}$ は, 隕石が内壁を貫通してしまわない様に防護できる厚さが必要である.

$$
t_{1}=\frac{t_{2}}{2.10}=0.90 \mathrm{~mm}
$$

増幅器には，レーザーエネルギー以外に排熱されねばならない余分な熱が発生する，レーザー効率を $\eta_{\mathrm{L}}$, ドライバー 1 基の出力を $E_{\mathrm{L}}$ とすれば, この熱は,

$$
Q_{\mathrm{L}}=\left(\frac{1}{\eta_{\mathrm{L}}}-1\right) \times f \times E_{\mathrm{L}}
$$

である。この熱は, 増幅器の側面に配置されるヒートパイプ・ラジエーターを用いて排熱される。増幅器と 同様に, ヒートパイプも $1500 \mathrm{~K}$ で使用されるとする。 ヒートパイプ本数 $n$, 直径 $d$, 長さ $L$, 増幅器内部に 差し込まれる蒸発部長さを $l$ とすると, 次の方程式が与えられる.

$$
\left\{\begin{array}{l}
Q_{\mathrm{L}}=2 \pi d \times n N \times L \times \lambda_{\mathrm{R}} \\
Q_{\mathrm{L}}=2 \times \frac{\pi d}{4} \times n N \times \frac{\lambda_{\mathrm{a}}}{(L+l)^{1 / 3}} \\
n N d=L_{\mathrm{L}}(=4 \mathrm{~m}) \\
l=\frac{Q_{\mathrm{L}} / \lambda_{\text {con }}}{\pi d \times n N}
\end{array}\right.
$$


ここで $\lambda_{\mathrm{R}}$ は単位表面積当たりの輻射率， $\lambda_{\mathrm{a}}$ は軸方向熱流束，lは蒸発部の長さ， $\lambda_{\text {con }}$ はレーザー ガスと蒸発部の熱伝達係数である。計算には $\lambda_{\text {con }}=2 \times 10^{6} \mathrm{~W} / \mathrm{m}^{2}, \quad \lambda_{\mathrm{R}}=2.44 \times 10^{5} \mathrm{~W} / \mathrm{m}^{2}, \quad \lambda_{\mathrm{a}}=1.46 \times 10^{8} \mathrm{~W}$ $/ \mathrm{m}^{2}$ を用いる。

蒸発部の長さlがレーザー本体の半径を越えることが考えられるが, これは, 蒸発部にフィンをつける などの表面積を大きくとる工夫をすることにより，蒸発部の長さを短くおさえなければならない．

レーザー用ヒートパイプの重量は，以下の式で与えられる．

$$
\left\{\begin{array}{l}
M_{\mathrm{HP}}=24 \times \rho_{\text {wall }} \times t_{\mathrm{L}} \times \frac{Q_{\mathrm{L}}}{\lambda_{\mathrm{R}}} \\
M_{\text {evap }}=24 \times \rho_{\text {wall }} \times t_{\mathrm{L}} \times \frac{Q_{\mathrm{L}}}{\lambda_{\text {con }}} \\
M_{\mathrm{Li}}=24 \times \rho_{\mathrm{Li}} \times 2 n \times \pi d \times \frac{c d}{2} \times(L+l)
\end{array}\right.
$$

ここで, $M_{\mathrm{HP}}, M_{\mathrm{evap}}, M_{\mathrm{Li}}$ はそれぞれヒートパイプ材, 蒸発部, ヒートパイプ内 Li の重量を表し， $\rho_{\text {wall, }}$ $\rho_{\mathrm{Li}}$ はそれぞれヒートパイプ材, $\mathrm{Li}$ の密度を表す。 $t_{\mathrm{L}}$ はヒートパイプ壁の厚さであり， $t_{\mathrm{L}}=0.75 \mathrm{~mm}$ と する。

\section{$2-4-2$ ミラー}

レーザーをターゲットに照射するためには，反射ミラーによって数回反射させ集光する必要がある． ミラーに照射損傷を引き起こさない照射強度 $E_{\mathrm{d}}$ を $40 \mathrm{~kJ} / \mathrm{m}^{2}$ とするとミラー 1 基の面積は, $S_{\mathrm{mr}}=E_{\mathrm{L}} / E_{\mathrm{d}}$ で ある. $E_{\mathrm{L}}$ はドライバー 1 基の出力エネルギーで $220 \mathrm{~kJ}$ であるので, $S_{\mathrm{mr}}=5.5 \mathrm{~m}^{2}$ である. ミラーの総重量は 次式で与えられる.

$$
M_{\mathrm{mr}}=24 \times \chi \times \rho_{\mathrm{mr}} \times t_{\mathrm{mr}} \times S_{\mathrm{mr}}
$$

ミラーには $\mathrm{Al}$ を使用し，厚さ $t_{\mathrm{mr}}=1 \mathrm{~cm}$ とする。 $\chi$ はレーザーの反射回数で, ここでは 4 回と仮定する

\section{2-5 その他のコンポーネント}

\section{2-5-1 ペイロードシールド}

核融合燃料としてDT燃料を用い, ペレット中での中性子減速を考慮すると，核融合爆発のエネルギーの 内, 約 6 割は $14 \mathrm{MeV}$ 中性子のエネルギーとなる。図2-5のように, 核融合爆発点より約 $200 \mathrm{~m}$ 離れた所に居住 


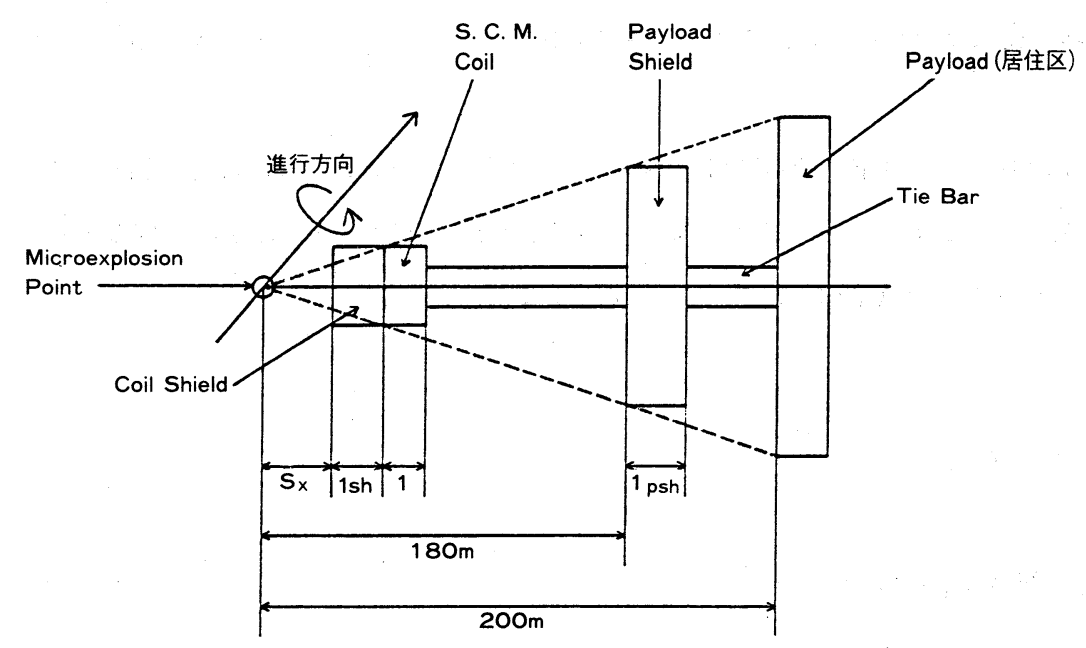

図2-5. 設計に用いるペイロードシールド配置図.

区域（Payload）を配置するが，コイル後方表面より居住区域まで何の遮蔽もしなかった場合，仮にペレッ トゲイン 500 , ドライバーエネルギー $5 \mathrm{MJ}$ とすると, 居住地域での中性子線量は, $5 \times 10^{7} \mathrm{rem} /$ 年にもなる. 従って, 居住区域前方にシールド（Payload Shield）を配置する必要がある，居住地域における中性子線量 は，次のようにして計算する。まず，コイルシールドへ入射する中性子のエネルギー束 $E_{\mathrm{csh}}$ を求める。

$$
E_{\mathrm{csh}}=\frac{\alpha_{\mathrm{n}} \times E \times G \times f}{4 \pi L_{\mathrm{sh}}^{2}}
$$

ここで， $L_{\mathrm{sh}}$ は核融合爆発点からコイルシールドまでの距離である.

中性子 1 個による壁面負荷 $W_{\mathrm{n}}$ は, 文献11)では, $W_{\mathrm{n}}=2.97 \times 10^{-11}\left(\mathrm{~W} / \mathrm{m}^{2}\right)$ である. よって, コイルシー ルドへ入射する中性子の個数 $N_{\mathrm{n}}$ は,

$$
N_{\mathrm{n}}=\frac{E_{\mathrm{csh}}}{W_{\mathrm{n}}}=3.37 \times 10^{10} \times E_{\mathrm{csh}}
$$

となる. 文献11)によれば, $1 \mathrm{~m}$ 厚さの $\mathrm{Li}_{2} \mathrm{O}$ 後方表面の $14 \mathrm{MeV}$ 中性子 1 個による線量当量は, $3.62 \times 10^{-10}$

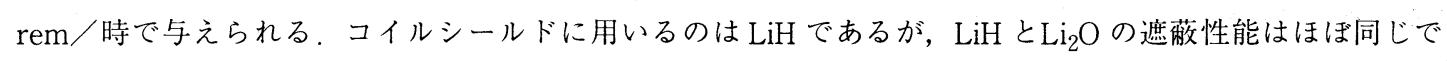
あるので, これを利用すれば, コイル後方表面の中性子線量当量 $S_{\mathrm{csh}}$ は, 次の式で与えられる. 


$$
\begin{aligned}
S_{\mathrm{csh}} & =3.62 \times 10^{-10} \times N_{\mathrm{n}} \times \exp \left(-\frac{l_{\mathrm{sh}}-1}{\lambda_{\mathrm{LiH}}}\right) \\
& =12.2 \times E_{\mathrm{csh}} \times \exp \left(-\frac{l_{\mathrm{sh}}-1}{\lambda_{\mathrm{LiH}}}\right) \quad(\mathrm{rem} / \text { 時 })
\end{aligned}
$$

ここで， $l_{\mathrm{sh}}$ はコイルシールド厚さ， $\lambda_{\mathrm{LiH}}$ は $\mathrm{LiH}$ の $14 \mathrm{MeV}$ 中性子に対する平均自由行程である.

さらに, この中性子は, コイルカンによっても減速される. 従って, コイル後方表面の中性子線量当量 $S_{\mathrm{scm}}$ は結局,

$$
S_{\mathrm{scm}}=S_{\mathrm{csh}} \times \exp \left(-\frac{l_{\mathrm{can}}}{\lambda_{\mathrm{can}}}\right)
$$

となる。ここで， $l_{\mathrm{can}}$ はコイルカン厚さ， $\lambda_{\mathrm{can}}$ はコイルカンの $14 \mathrm{MeV}$ 中性子に対する平均自由行程で あって，組成を仮にC $100 \%$ とすれば， $\lambda_{\mathrm{can}}=6.35 \mathrm{~cm}$ を用いる。

ペイロードシールド配置位置を核融合爆発点より $180 \mathrm{~m}$ の地点とすれば，そこに入射する中性子線量は，

$$
S_{\mathrm{psh}}=S_{\mathrm{scm}} \times \frac{L_{\mathrm{c}}^{2}}{180^{2}}
$$

である。ここで， $L_{\mathrm{c}}$ は核融合爆発点よりコイル後方表面までの距離である. ペイロードシールドには $\mathrm{LiH}$ を使用するが，その厚さを $l_{\mathrm{psh}}$ とすれば，ペイロードシールド後方表面での線量当量 $S_{\mathrm{psh}}$ out は,

$$
S_{\mathrm{psh}}^{\text {out }}=S_{\mathrm{psh}} \times \exp \quad\left(-\frac{l_{\mathrm{psh}}}{\lambda_{\mathrm{LiH}}}\right)
$$

である，居住区域での線量当量 $S_{\mathrm{pl}}$ は，逆 2 乗の法則により，

$$
S_{\mathrm{pl}}=S_{\mathrm{psh}} \text { out } \times \frac{\left(180+l_{\mathrm{psh}}\right)^{2}}{200^{2}}
$$

となる。ここでは， $S_{\mathrm{pl}}$ を $1 \mathrm{rem} /$ 年以下になるように $l_{\mathrm{psh}}$ を計算する． 
また，コイル後方全てにペイロードシールドを配置すると, 重量 $M_{\mathrm{psh}}$ が大きくなりすぎるので, 配置す るのは 1 部だけとし，居住区域を制限することにする。ペイロードシールド重量 $M_{\mathrm{psh}}$ を一定としたとき， 居住区域の割合 $\Sigma_{\text {crew }}$ は, 次式で与えられる。

$$
\Sigma_{\text {crew }}=\frac{M_{\mathrm{psh}}}{\rho_{\mathrm{LiH}} \times l_{\mathrm{psh}} \times\left(4 \pi \times 180^{2} \times \frac{\Omega}{4 \pi}\right)}
$$

ここで, $\frac{\Omega}{4 \pi}$ はコイルの占める立体角である. 上式の分母は, コイル後方全てに配置したときのペイ ロードシールド重量を表す．ターゲット設計のところで述べた様に推進材として, 水素も積み込まれる。こ の水素を遮蔽材として用いることができるので航行の初期には, 実際は $\Sigma_{\text {crew }}$ はもっと広くとれる。

\section{2-5-2 冷凍システム ${ }^{4)}$}

核融合ロケットでは, 磁場の生成のために超電導コイルを用いるが, 超電導コイルには冷却が必要であ る。また,ピックアップコイルの電送線には $\mathrm{Al}$ を低温にし抵抗率を小さくして用いるので,ここにも冷却 が必要である。これらの冷却には，冷凍機を用いる。

低熱源に $P_{\text {low }}$ の熱源があるとき，これを高熱源へ供給するために要する熱量 $P_{\text {high }}$ は，次式で与えら れる。

$$
P_{\text {high }}=\frac{1}{\eta \times \beta_{\mathrm{R}}} \times P_{\text {low }}
$$

ここで, $\eta$ はポンプ効率, $\beta_{\mathrm{R}}$ は冷凍機成績係数であり, 次式で与えられる.

$$
\beta_{\mathrm{R}}=\frac{T_{1}}{T_{1}-T_{2}}
$$

ここで, $T_{1}, T_{2}$ はそれぞれ 高熱源と低熱源の温度で ある。

核融合ロケットでは, 図 2-6に示すような熱の流れ で，超電導コイル $(4.2 \mathrm{~K})$ と電送線 (20K) に発生す

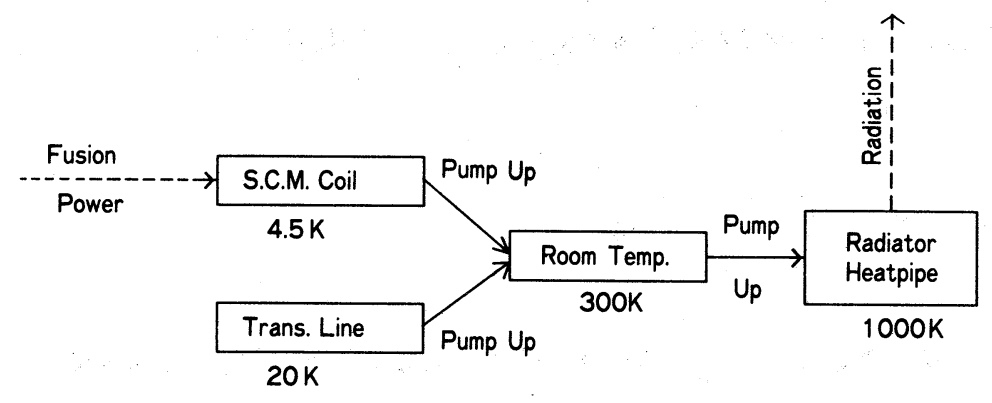

図2-6. 熱の流れ図. 
る熱は, 一度室温（30K）に引き上げ，さらに1000Kによで引き上げた後，ヒートパイプで排熱する．

$4.2 \mathrm{~K}$ から $300 \mathrm{~K}$ へ引き上げるためにはクロード機関を用い，それ以外にはスターリング機関を用いる。そ れぞれの機関についての重量は，次式で与えられる.

$$
\begin{gathered}
M_{\text {claude }}=0.167 \times P_{\text {low }}{ }^{2 / 3} \text { (tons) } \\
M_{\text {stirling }}=\rho_{\text {st }} \times P_{\text {high }}(\text { tons })
\end{gathered}
$$

$\rho_{\mathrm{st}}$ は，使用するスターリング機関の熱量に対する重量比（tons/We）である.

1000K で使用されるヒートパイプの重量は，

$$
M_{\mathrm{HP}}=\rho_{\text {wall }} \times t \times \frac{Q}{\lambda_{\mathrm{R}}}
$$

である。ここで, $\rho_{\text {wall }}$ はヒートパイプ壁材密度， $Q$ は排熱される熱量， $\lambda_{\mathrm{R}}$ は1000Kにおける単位表面 積当たりの輻射率である。

\section{2-5-3 燃料タンク}

核融合ロケットの燃料として, 核融合燃料ターゲット（アブレーター材を含む）と推力調整用の推進材が ある。これらを貯蔵しておくタンクは球形であると仮定し，その半径を $R_{\mathrm{T}}$ とすれば,

$$
R_{\mathrm{T}}=\left(\frac{3 M_{\mathrm{F}}}{4 \pi \rho_{\mathrm{F}}} \times \frac{1}{\beta_{\mathrm{M}}}\right)^{1 / 3}
$$

である：ここで, $M_{\mathrm{F}}$ は燃料重量, $\rho_{\mathrm{F}}$ は燃料密度, $\beta_{\mathrm{M}}$ は燃料のタンク内体積占有率である.

燃料重量は, 最大でも6000ton 程度と考えられる。 また, 燃料の大半は推進材に使用される水素であり, スラッシュ状態で貯蔵するとし，密度は $0.0763 \mathrm{~g} / \mathrm{cm}^{3}$ とする，体積占有率を $75 \%$ と仮定すれば，タンクの半 径は最大でも $13.6 \mathrm{~m}$ である。

タンク壁の厚さを $t_{\mathrm{L}}$ とすれば,

$$
t_{\mathrm{L}}=\frac{P R_{\mathrm{T}}}{2 \sigma_{\mathrm{u}}}
$$


である。ここで， $\sigma_{\mathrm{u}}$ は壁材の使用応力であり，壁材にSUS を使用すれば， $\sigma_{\mathrm{u}}=100 \mathrm{MPa}$ 程度である． $P$ は夕ンク内の圧力であり, 水素の飢和蒸気圧 $P_{1}$ と, ロケットの加速により燃料がかける圧力 $P_{\mathrm{H}}$ から なる。

$$
P_{\mathrm{H}}=\rho_{\mathrm{F}} \times a \times 2 R_{\mathrm{T}}
$$

ここで， $a$ はロケットの加速度であり，最大でも $10 \mathrm{~cm} / \mathrm{sec}^{2}$ 程度である. 水素の $13.8 \mathrm{~K}$ （三重点）における 飢和蒸気圧は7.2KPa 程度であるので, 内圧は約7.4 $\mathrm{KPa}$ である ${ }^{12)}$ 。従って, タンク重量は

$$
M_{\mathrm{T}}=4 \pi R_{\mathrm{T}}^{2} \times t_{\mathrm{L}} \times \rho_{\mathrm{t}}
$$

と見積られ, 最大でも約 12 ton であると考えられる。ここで, 密度 $\rho_{\mathrm{t}}=10.9 \mathrm{~g} / \mathrm{cm}^{3}$ とした．

\section{2-5-4 タイ・バー（支持柱）}

ロケットのコンポーネントを支持するために, タイバーが必要である.夕イバーには, $F=\dot{m} \omega f(\mathrm{~N})$ の力 が加えられる。ここで, $\dot{m}$ は夕ーゲット重量, $\omega$ は核融合プラズマの排出速度， $f$ は核融合周波数である.

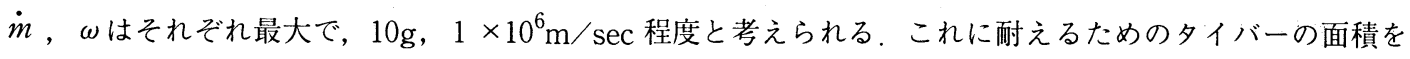

$$
S_{\mathrm{TB}}=\frac{F}{\sigma_{\mathrm{u}}}
$$

とする， $\sigma_{u}$ は夕イバー材の使用応力で，グラスファイバーを用いれば， $\sigma_{u}=330 \mathrm{MPa}$ 程度である. 重量 は次の式で与えられる.

$$
M_{\mathrm{TB}}=\rho_{\mathrm{TB}} \times S_{\mathrm{TB}} \times L_{\mathrm{TB}}
$$

$\rho_{\mathrm{TB}}$ は夕イバー材の密度で, $\rho_{\mathrm{TB}}=1.89 \mathrm{~g} / \mathrm{cm}^{3}$ とする. $L_{\mathrm{TB}}$ は夕イバーの長さである.

$L_{\mathrm{TB}}=200 \mathrm{~m}$ と仮定すれば, $M_{\mathrm{TB}}$ は $0.01 \times f($ ton $)$ となる.

\section{2-5-5 始動用原子炉 ${ }^{13)}$}

ロケットが飛行中の時は, レーザーを照射するためのエネルギーは, 核融合爆発からピックアップコイル を通して得られるが，ロケットが始動する際には，そのようなエネルギーを得ることはできない，そのため 


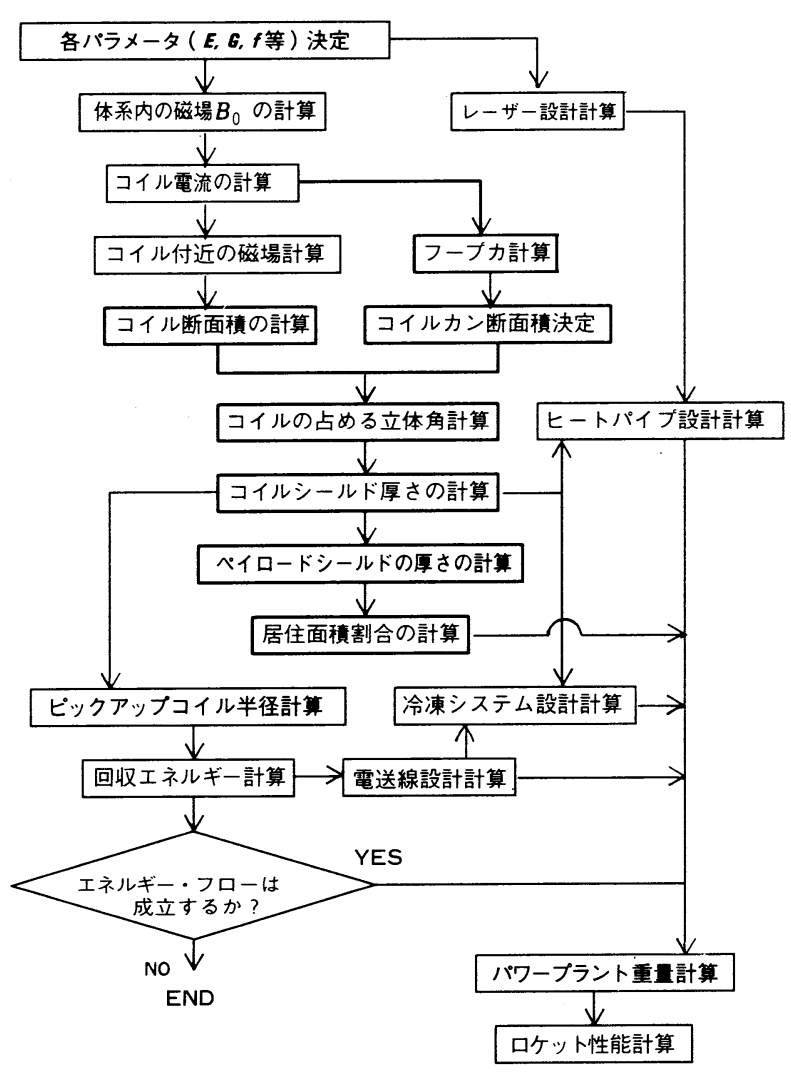

図2-7. 設計のフローチャート.

$P=\alpha_{\mathrm{P}} \times E \times G \times f \times f_{\mathrm{T}}{ }^{2}$
に，始動用の原子炉を積んでおく必要が ある。

この原子炉に，75kWe の発電を行う方 式をとれば，その重量は約 5 ton 程度と なると考えられる。

\section{2-6 パワープラント重量}

2 章で述べた以上のコンポーネントを ロケットのパワープラントとし，その総 重量をパワープラント重量 $M_{\mathrm{p}}$ とする. 今までに述べた，設計のフローチャート を図2-7に示す。

\section{3. ロケットの性能計算}

\section{3-1 ロケット性能 ${ }^{14)}$}

ロケットの出力 $P$ は, ドライバーエ ネルギーを $E$, ペレットゲインを $G$, 核融合周波数を $f$, 推力への変換効率 （運動量）を $f_{\mathrm{T}}$ とすると, 次の式で与 えられる。

$\alpha_{\mathrm{P}}$ は核融合エネルギー中で荷電粒子の占める割合である。推進材の排出速度を $\omega(t)$, ロケットの重量を $M(\mathrm{t})$ とすると, 次のようにも表せる.

$$
P=-\frac{1}{2} \times \frac{\mathrm{d} M(t)}{\mathrm{d} t} \times \omega(t)^{2}
$$

またロケットの加速度 $a(t)$ は,

$$
a(t)=-\frac{\mathrm{d} M(t)}{\mathrm{d} t} \times \omega(\mathrm{t}) \times \frac{1}{M(t)}
$$


である. 式 (3-1-2), (3-1-3) より

$$
-\frac{\mathrm{d} M(t)}{\mathrm{d} t} \times \frac{1}{M(t)^{2}}=\frac{a(t)^{2}}{2 P}
$$

という関係式が得られる.

加速度 $a(t)$ は $t$ の一次式であるとし, 航行時間 $T(\mathrm{sec})$ の半分を加速し, 残りを減速すると仮定す ると, 次の方程式が得られる.

$$
\left\{\begin{array}{l}
a(t)=\alpha t+C \\
a(T / 2)=0 \\
v(t)=\int_{0}^{t} a(t) \mathrm{d} t \\
D=\int_{0}^{T} v(t) \mathrm{d} t
\end{array}\right.
$$

ここで， $\alpha, C$ は定数であり，D航行距離である．この方程式を解くと,

$$
a(t)=\frac{12 D}{T^{3}}\left(\frac{T}{2}-t\right)
$$

となる.

ロケットのパワープラント重量を $M_{\mathrm{P}}$, ペイロード重量を $M_{\mathrm{L}}$, 燃料（核融合ターゲット十推進材）重量を $M_{\mathrm{F}}$ とする. 距離 $\mathrm{D}$ を往復するとして, 片道に時間 $T$ を要するとする. 出発時のロケット重量 $M(0)$, 䚻還時 のロケット重量 $M(2 T)$ はそれぞれ次のように仮定する.

$$
\begin{aligned}
& M(0)=M_{\mathrm{P}}+M_{\mathrm{L}}+M_{\mathrm{F}} \\
& M(2 \mathrm{~T})=M_{\mathrm{P}}+M_{\mathrm{L}}
\end{aligned}
$$

式（3-1-4）を上の条件に合わせて積分すれば, 


$$
\begin{aligned}
\frac{1}{M(2 T)}-\frac{1}{M(0)} & =\frac{1}{2 \mathrm{P}}\left\{\int_{0}^{T} a(t)^{2} \mathrm{~d} t+\int_{T}^{2 T} a(t)^{2} \mathrm{~d} t\right\} \\
& =\frac{12 D^{2}}{P T^{3}}
\end{aligned}
$$

となる。ここで簡単のために，次のような定義をする．

$$
\alpha \equiv \frac{6 D^{2}}{\eta T^{3}}
$$

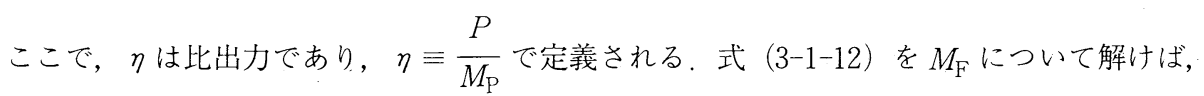

$$
M_{\mathrm{F}}=\frac{\alpha\left(M_{\mathrm{P}}+M_{\mathrm{L}}\right)^{2}}{M_{\mathrm{P}}-2 \alpha\left(M_{\mathrm{P}}+M_{\mathrm{L}}\right)}
$$

である。この式より， $\alpha \geqq \frac{M_{\mathrm{P}}}{2\left(M_{\mathrm{P}}+M_{\mathrm{L}}\right)}$ となると， $M_{\mathrm{F}}$ が負になり，ロケットとして成立しなくなることが わかる。

次にターゲットのイオン化について考慮する。式 (3-1-2) (3-1-3) より， $\omega(t)$ について解けば,

$$
\omega(t)=\frac{2_{P}}{a(t) M(t)}
$$

である。ここで, $M(t)$ は式 (3-1-4) を積分することにより求めることができる。この時, ターゲット 1 個 当たりの重量（推進材を含む）は，(3-1-2）式より，

$$
\dot{m}(\mathrm{t})=\frac{2 P}{f \omega(t)^{2}}\left(f \dot{m}=-\frac{\mathrm{d} M}{\mathrm{~d} t}\right)
$$

という式で求めることができる.

推進材は，核融合エネルギー中の荷電粒子によりイオン化され，推力変換に利用されるのであるが，その 重量が大きすぎると，イオン化に費やされるエネルギーが大きくなり過ぎ，核融合エネルギーから推力への 変換ができなくなってしまう，核融合エネルギー中の荷電粒子が持つエネルギーの内で，推進材のイオン化 に費やされるエネルギーの割合の上限を $1 \%$ と仮定すれば，H１ｇをイオン化するのに必要なエネルギーは 
$1.31 \mathrm{MJ}$ であるから, ターゲット1 個の重量の上限は次のように与えられる。

$$
\dot{m}_{\max }=\frac{E \times G \times \alpha_{\mathrm{P}} \times 0.01}{1.31 \times 10^{6}}(\mathrm{~g})
$$

（3-1-16）式で求めるターゲット1 個の重量が, 上記の $\dot{m}_{\max }$ を越えてしまう場合には, ロケットとして成 立しなくなるとする，ターゲット重量は， $t=0$ のとき最大となるので，そのときのみ検討すればよい． この時, $\alpha<\frac{M_{\mathrm{P}}}{2\left(M_{\mathrm{P}}+M_{\mathrm{L}}\right)}$ となるのは, 明らかである.

以上の条件を考慮すれば，航行距離 $D$ に対する最短航行時間 $T_{\min }$ を得ることができる，ロケット性能と して,この $T_{\min }$ を評価する。

式（3-1-1)，(3-1-14)，(3-1-15)，(3-1-16）より，ターゲット1個当たりの重量に関し，次の式が得ら れる。

$$
\dot{m}=\frac{2 P}{f} \times \frac{9 D^{2} T^{2} M_{\mathrm{PL}}^{2}}{\left(P T^{3}-12 M_{\mathrm{PL}} D^{2}\right)^{2}}\left(M_{\mathrm{PL}} \equiv M_{\mathrm{P}}+M_{\mathrm{L}}\right)
$$

$\dot{m}=\dot{m}_{\text {max }}$ の時, ロケットは最大の推力を得, さらには $T=T_{\min }$ を得る.よって, 式(3-1-17),(3-1-18) を等しいとおいて次の式を得る.

$$
\frac{P}{M_{\mathrm{PL}}}=12 \frac{D^{2}}{T^{3}}+9.98 \times 10^{6} \times \frac{D}{T^{2}}
$$

$\frac{P}{M_{\mathrm{PL}}}$ は, 比出力 $\left(\equiv \frac{P}{M_{\mathrm{P}}}\right)$ と次のような関係がある.

$$
\frac{P}{M_{\mathrm{PL}}}=\frac{\eta}{1+\frac{M_{\mathrm{L}}}{M_{\mathrm{P}}}}
$$

$D$ が定で，Tが減少すれば，右辺は大きくなる，従って性能を良くするためには $\frac{P}{M_{\mathrm{PL}}}$ （あるいは を大きくすれば良いことがわかる，Pはパラメーター $E, G, \alpha_{\mathrm{P}}, f, f_{\mathrm{T}}$ の関数であり, 式(3-1-1) の様に 表される， $M_{\mathrm{PL}}$ も $E, G, \alpha_{\mathrm{P}}, f, f_{\mathrm{T}}$ の変化により值は変化するものの，その関係を表記することは困難で ある，従って， $M_{\mathrm{PL}}$ はパラメー夕を変化される度に 2 章で述べた式により計算する必要がある. 


\section{3-2 ロケットの性能計算及び結果}

\section{3-2-1 性能に対するペレットゲイン依存性について}

ドライバーエネルギーを $5 \mathrm{MJ}$ ，核融合周波数を $30 \mathrm{HZ}$ とし，ターゲット材としてDT 燃料を用いる。このと き，ペレットゲイン $G=500,1000,1500 に つ い て ，$ 性能計算を行った。その際に用いたロケット重量デー 夕を表3-1に示す。ペイロード重量は100tonとする。 性能計算の結果を, 図3-1に示す。

この結果， $G=500$ 1000まででは，ゲインが大きく なるにつれて，性能が良くなっているが，1000を超え ると，それほど性能が良くなっているとは言えない，

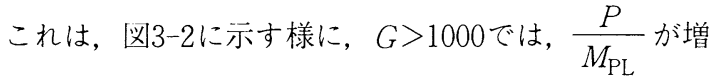
加しないためである：口ケット出力 $P$ が増大すると $M_{\mathrm{PL}}$ も増加する. 式 (3-1-19) に示す様に $\frac{P}{M_{\mathrm{PL}}}$ が増 加しないと性能が良くならない. $M_{\mathrm{PL}}$ の増加の主な原因は, 表3-1に示されているように, 出力 $P$ の増大に 伴う中性子エネルギーの排除に要するラジエーター重量の増加であると言える.
表3-1。ロケット重量データ $(f=30 \mathrm{~Hz}$, DT 然料 $)$

\begin{tabular}{|l|c|c|c|}
\hline \multicolumn{1}{|c|}{ Gain } & 500 & 1000 & 1500 \\
\hline Thrust Chamber & \multicolumn{2}{|c|}{175} & \multicolumn{2}{|c|}{291} & \multicolumn{2}{c|}{616} \\
Coil & 37 & 45 & 67 \\
Shield & 94 & 111 & 145 \\
Radiator & 44 & 135 & 404 \\
Power System & \multicolumn{2}{|c|}{45} & \multicolumn{2}{|c|}{55} & \multicolumn{2}{c|}{63} \\
Pickup Coil & 0.7 & 0.7 & 0.7 \\
Capacitor & 19 & 19 & 19 \\
Trans. Line & 25 & 35 & 43 \\
Driver System & \multicolumn{2}{|c|}{152} & \multicolumn{2}{|c|}{152} & 152 \\
Laser & 31 & 31 & 31 \\
Radiator & 107 & 107 & 107. \\
Mirror & 14 & 14 & 14 \\
Payload Shield & 100 & 100 & 100 \\
Tank & 12 & 12 & 12 \\
Tie Bar & 0.03 & 0.03 & 0.03 \\
Refrig. System & 3 & 4 & 4 \\
Startup Reactor & 5 & 5 & 5 \\
\hline Total & 492 & 619 & 952 \\
\hline
\end{tabular}

(ton)

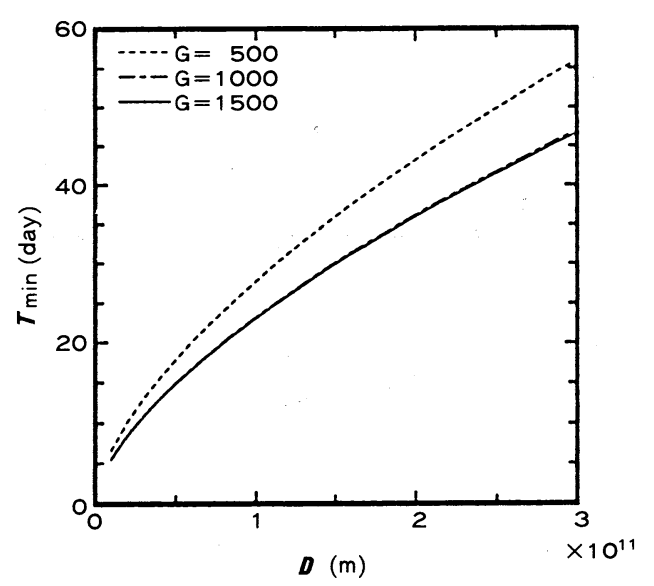

図3-1. ロケット性能 (D- $T_{\min }$ 図) ( G の依存性).

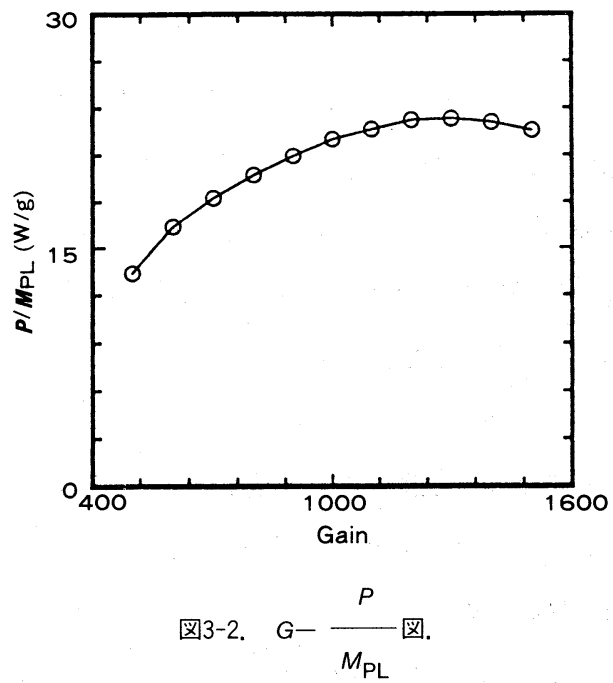

\section{3-2-2 性能に対する核融合周波数依存性について}

ターゲット材として DT 燃料を用い, ドライバーエネルギー5MJ, ペレットゲイン 1500 とする。このとき 核融合周波数 $f=10,30,50 \mathrm{~Hz}$ についての計算を行った。その際に用いたロケット重量データは表3-2に示 す。ペイロード重量は100ton とする。性能計算の結果は，図3-3に示す， 
表3-2. ロケット重量データ（ $G=1500, D T$ 燃料)

\begin{tabular}{|c|c|c|c|}
\hline Rep. Rate & $10 \mathrm{~Hz}$ & $30 \mathrm{~Hz}$ & $50 \mathrm{~Hz}$ \\
\hline Thrust Chamber & 270 & 616 & 1945 \\
\hline Coil & 67 & 67 & 67 \\
\hline Shield & 137 & 145 & 148 \\
\hline Radiator & 66 & 404 & 1730 \\
\hline Power System & 63 & 63 & 63 \\
\hline Pickup Coil & 0.7 & 0.7 & 0.7 \\
\hline Capacitor & 19 & 19 & 19 \\
\hline Trans. Line & 43 & 43 & 43 \\
\hline Driver System & 76 & 152 & 257 \\
\hline Laser & 31 & 31 & 31 \\
\hline Radiator & 31 & 107 & 212 \\
\hline Mirror & 14 & 14 & 14 \\
\hline Payload Shield & 100 & 100 & 100 \\
\hline Tank & 12 & 12 & 12 \\
\hline Tie Bar & 0.01 & 0.03 & 0.05 \\
\hline Refrig. System & 3 & 4 & 5 \\
\hline Startup Reactor & 5 & 5 & 5 \\
\hline Total & 529 & 952 & 2387 \\
\hline
\end{tabular}

この結果, $f=10 \mathrm{~Hz} \sim 30 \mathrm{~Hz}$ までは, $f$ が大きくな るにつれて性能が良くなっているが， $30 \mathrm{~Hz}$ を超える と性能は劣ってきている。これは図3-4に示す様に，P の増大率よりも， $M_{\mathrm{PL}}$ の増大率が大きくなった結果 $\frac{P}{M_{\mathrm{PL}}}$ が, 減少するからである。また, 重量 $M_{\mathrm{PL}}$ 増加 の原因は， $P$ の増大に伴う中性子エネルギーの排除に 要するラジエーター重量の増加，及び $f$ をきくす るために必要なドライバーシステム重量の増加である と言える。（表3-2参照）

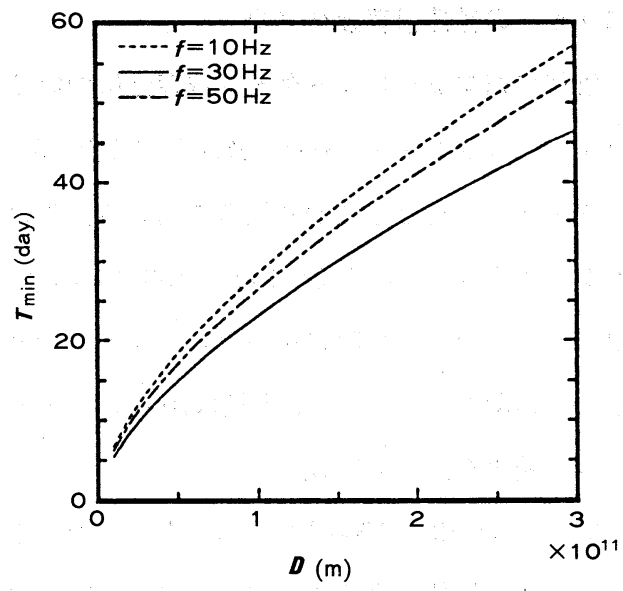

図3-3. ロケット性能 $\left(D-T_{\min }\right.$ 図) ( $f$ の依存性).

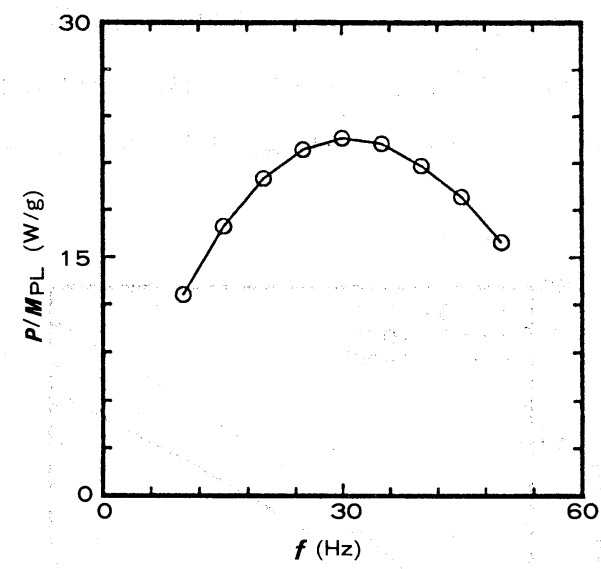

図3-4. $t-\frac{P}{M_{\mathrm{PL}}}$ 図.

\section{3-2-3 ロケット性能に対する燃料の依存性}

次に，ターゲット燃料を変え， DD, D ${ }^{3} \mathrm{He}$ を用いた場合を計算した。ここで，ドライバーエネルギーを $5 \mathrm{MJ}$ ，核融合周波数を $30 \mathrm{~Hz}$ とし，ペレットゲインは，2020年代の技術で予想されるものとし， DD, D ${ }^{3} \mathrm{He}$ と もに250とした ${ }^{2}$ 。（表2-1参照）この際に用いた重量データを表3-3に示す。ペイロード重量は100ton とす る。性能計算の結果を図3-5に示す。

この結果, $\mathrm{D}^{3} \mathrm{He}$ 燃料を用いた場合, DT 燃料 $(G=1500)$ とほぼ同様の結果を得, DD 燃料を用いた場合は 性能が劣ることがわかった。表3-4に亦されるように $\frac{P}{M_{\mathrm{PL}}}$ 值が，DTと $\mathrm{D}^{3} \mathrm{He}$ はほほ同じで，DDは小さくな る為である. DTに比して $\mathrm{D}^{3} \mathrm{He}$ では, 出力 $P$ は劣るものの, 表3-3に示す様に中性子エネルギー排除に関 するコンポーネントが必要でないため $M_{\mathrm{PL}}$ が小さくなる. 
表3-3. ロケット重量データ $\quad(f=30 \mathrm{~Hz})$

\begin{tabular}{|c|c|c|c|}
\hline Target & $D^{3} \mathrm{He}$ & DD & DT \\
\hline Thrust Chamber & 170 & 153 & 616 \\
\hline Coil & 65 & 45 & 67 \\
\hline Shield & 101 & 97 & 145 \\
\hline Radiator & 4 & 11 & 404 \\
\hline Power System & 60 & 51 & 63 \\
\hline Pickup Coil & 0.7 & 0.7 & 0.7 \\
\hline Capacitor & 19 & 19 & 19 \\
\hline Trans. Line & 40 & 31 & 43 \\
\hline Driver System & 152 & 152 & 152 \\
\hline Laser & 31 & 31 & 31 \\
\hline Radiator & 107 & 107 & 107 \\
\hline Mirror & 14 & 14 & 14 \\
\hline Payload Shield & 100 & 100 & 100 \\
\hline Tank & 12 & 12 & 12 \\
\hline Tie Bar & 0.03 & 0.03 & 0.03 \\
\hline Refrig. System & 3 & 3 & 4 \\
\hline Startup Reactor & 5 & 5 & 5 \\
\hline Total & 502 & 476 & 952 \\
\hline
\end{tabular}

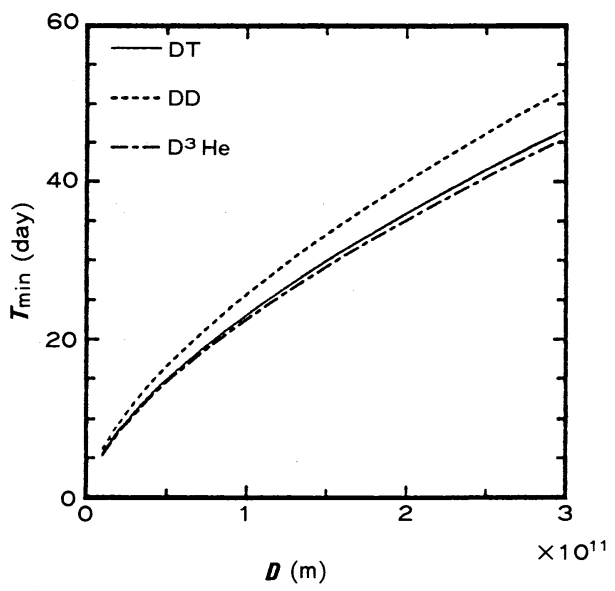

図3-5. ロケット性能 (D- $T_{\min }$ 図) (燃料の依存性).

表3-4. 燃料 $-\frac{P}{M_{\mathrm{PL}}}$ 比較表

\begin{tabular}{|c|c|c|c|}
\hline Target & $D^{3} \mathrm{He}$ & $\mathrm{DD}$ & $\mathrm{DT}$ \\
\hline Rocket Power $(P)$ & $14.3 \mathrm{GW}$ & $9.51 \mathrm{GW}$ & $23.8 \mathrm{GW}$ \\
\hline PowerPlant Mass $\left(M_{\mathrm{p}}\right)$ & 502 ton & 476 ton & 952 ton \\
\hline Payload Mass $\left(M_{\mathrm{L}}\right)$ & 100 ton & 100 ton & 100 ton \\
\hline$\frac{P}{M_{\mathrm{PL}}}$ & $23.8 \mathrm{~W} / \mathrm{g}$ & $16.5 \mathrm{~W} / \mathrm{g}$ & $22.6 \mathrm{~W} / \mathrm{g}$ \\
\hline
\end{tabular}

\section{3-2-4 他の推進システムとの比較}

これは大変難しい．もうすでに実用化している化学ロケット，あるいは実用化目前のイオン・スラスター， MPD (Magneto Plasma Dynamic) スラスターから, あまり設計が行われていない光子ロケットまで, 開発・ 実用化段階がそれぞれにより違い，またそれに対応して詳細に設計が行われ性能が正確に把握できるものか ら，ただ単に予測あるいは期待される性能が挙げられるものまで大変に広い範囲にわたるからである．

核融合ロケットに関して言えば，1960年代後半核融合の実用化が今すぐにでもできると非常な楽観論がま だ支配していた時期には，磁場閉じ込め方式の一種であるミラー型に基づいて多くの概念設計が提案されて いた ${ }^{15)}$ 。しかし，現在ではミラー型に関する大型の研究開発の計画は世界中にはない。磁場閉じ込め方式 では，トカマク型が開発競争で一歩先んじている，従って最近では，トカマク型に基づく核融合ロケットが 設計されている16)，17）、核融合プラズマの閉じ込め性能を劣化させることなく推力発生用に磁場配位を

（例えばダイバータを用いて）設計することが重要であろう。磁場閉じ込め方式では，強力な磁場によりプ ラズマを抒㧍う形で閉じ达める。従って, 磁場発生用のコイルは中性子の照射を受けるので, 重いシール ド，またシールドに落ちた中性子のエネルギーを排熱するための重いラジエーター（ヒートパイプ）が必要 となる，ロケット応用を考えるときは，DT 核融合反応は候補となりえず， DD， D ${ }^{3} \mathrm{He}$ 等の中性子発生量の少 
ない反応を利用したものになるであろうが，そのためには，さらに困難なプラズマ閉じ込め技術が要求され る.トカマク型ロケットの例として, Bussard の DD 燃料ロケット ${ }^{17)}$ では, $\frac{P}{M_{\mathrm{PL}}}$ は $1.8 \mathrm{~W} / \mathrm{g}, \eta$ は3.7W $/ \mathrm{g}$

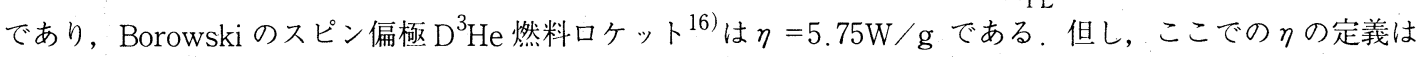
$\frac{P}{M_{\mathrm{PL}}}$ であり，Pとしては全核融合（熱）出力をとる，3-1の議論でも述べたように，クは大きいほど良いの であるが，本論文中の設計例では $231 \mathrm{~W} / \mathrm{g}$ であった，またVISTA では $120 \mathrm{~W} / \mathrm{g}$ である ${ }^{1)}$. 他の例は文献18)に まとめてある，但し，挙げられている数值は，1/クである。

米ソとも火星探査には, 現在のところ原子力推進ロケットを考えているようである, 従って, 核融合口 ケットの競争相手は, 原子力推進ロケットであろう。原子力推進ロケットでは, 最も有望と考えられるもの は核分裂電気推進型ロケットである。この型では, 核分裂炉は単なる電力発生装置として考えられており, その電力を利用して, イオン・スラスター, MPD スラスター, あるいはアークジェット等の電気推進システ ムを働かせることになる，文献18)に1/クが挙げられている，但し，出力は電気出力であり，ここでは熱出 力を用いていることに注意が必要である。熱から電力への変換効率はせいぜい $15 \%$ 程度と考えられるので, ここでの結果と比較すれば，約 1 桁の修正が必要である。典型的な例として， $5 \mathrm{~kg} / \mathrm{kW}$ (electric) をとる と, $2 \mathrm{~W} / \mathrm{g}$ ということになる.

従って，「ここで仮定された性能が実現化される」としたときに限れば, レーザー核融合ロケットが一番 有望であると考えられる.

\section{4. 結論}

核融合口ケットの性能に対する，ペレットゲイン，核融合周波数，燃料の種類等の依存性を求めた結果， 次の結論を得た。ここでは性能として，航行距離 $D$ に対する最短航行時間 $T$ m $\min$ をとった。

・ペレットゲイン $G に$ 関しては, ある程度の值までは $G$ が大きくなるにしたがい性能は良くなるが, 過剩 に大きくしても性能が良くなるとは言えない，本論文の計算からは $G=1300$ 程度が最適であった。

・核融合周波数 $f$ も, ペレットゲインと同様にある程度の值までは性能は良くなるが, 過剩に大きくし ても性能は良くならない，むしろこの場合，劣ってくると言っても良い，本論文の計算からは $f=30 \mathrm{~Hz}$ 程度が最適であった。

・燃料としては， ロケット出力 $P$ を大きくとれるDT 燃料，または，中性子に関する重量がほとんど無 いためにロケット重量 $M_{\mathrm{PL}}$ が小さく設計できる $\mathrm{D}^{3} \mathrm{He}$ が，適していると思われる．

・他の推進システムとの比較から，核融合ロケットが大変有望であることが示される．

以上が本論文の結論であるが，ペレットゲインについて言えば，現状ではドライバーエネルギー $5 \mathrm{MJ} に$ 対するゲインは図2-1に示されるように一番楽観的に見積っても $G=1000$ 程度とされており，1000を超える

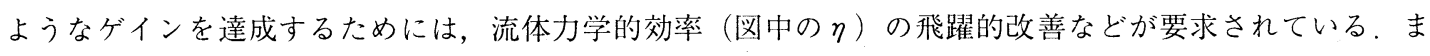
た，ピックアップコイルによるエネルギー回収についも本論文中では，あくまでも概算しか行っておらず， 
文献19)のような詳しい計算も必要と考えられる。ドライバーの設計でも，KrFレーザー用電子ビーム励起 装置などを考慮する必要がある，以上のような点について，今後の調査，研究の余地を残している。

地上用レーザー核融合炉では，典型的には $G=100 \sim 400, f=1 \sim 10 \mathrm{~Hz}$, レーザーエネルギー $1 \sim 10 \mathrm{MJ}$ 程度である。ロケットに対しては, 要求性能が若干高い様であるが, 地上用では炉キャビティ内でのトリチ ウム増殖, 熱エネルギー変換, 衝撃波からの防護等, 厄介な問題を考える必要がある。推力変換には, プラ ズマと磁場の相互作用を利用する訳であるが，磁場閉じ込め方式で見られる様な各種不安定性が予測されて いる，最終的には実験で確かめる必要があるが, single shotベースの実験炉で早い時間に行うことになる であろう。ドライバーの開発も含めて，地上用の炉開発スケジュールにうまく取り込んでおく必要がある。

本論文をまとめるに当たり，多くの方に議論していただいた。ここに，感謝の意を表します。また，本論 文について，多くの方のコメントや意見をいただきたい.

\section{参考文献}

1) C.D. Orth et al. : UCRL-96676 (1987).

2) C. D. Orth : Proc. Special Minicourse on Fusion Applications in Space (1988) 113.

3) J. Meyer-Ter-Vehn : Nucl. Fusion 22 (1982) 561.

4) R.A. Hyde et al. : AIAA Paper No. 72-1063 (1972).

5) 電気学会通信教育会著: 超電導工学（オーム社, 東京, 1974).

6) G.P. Lasche : UCRL-53434 (1983).

7) A. Bond and A.R. Martin : J. Brit. Interplanetary Soc., Project Daedalus Final Report, (1978) S63.

8) R.W. Werner and G. A. Carlson : UCRL-50294 (1967).

9) L. A. Glenn and D. A. Young: Nucl. Eng. Des., 54 (1979) 1.

10) D.B. Harris : Fusion Technol. 11 (1987) 705.

11) Y. Seki et al. : JAERI-M 82-054 (1982).

12) P.C. Souers: Hydrogen Properties for Fusion Energy, (University of California Press, London, England, 1986).

13）安田秀志，他：第 9 回宇宙エネルギーシンポジウム, (1990) 30

14) R.A. Hyde : UCRL-88857 (1983).

15）深井佑造：“科学朝日”（Mar. 1989） 24 また, 河島信樹他, 核融合研究31 (1974) 244. も参照のこと.

16) S.K. Borowski : AIAA Paper No. 87-1814 (1987).

17) R.W. Bussard : J. Propulsion 6 (1990) 567.

18) J.R. Roth : Fusion Technol. 15 (1989) 1375.

19) H. Nakashima et al. : Fusion Eng. Des. 掲載決定. 